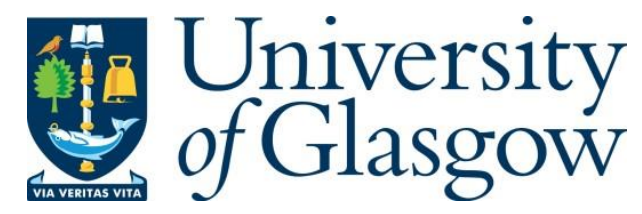

Bishop, P., Cuenca-Garcia, C. , Jones, R. and Cook, D. (2017) Lime burning in clamp kilns in Scotland's Western Central Belt: primitive industry or simple but perfectly adequate technology? Industrial Archaeology Review, pp. 1-23. (doi:10.1080/03090728.2017.1292642)

This is the author's final accepted version.

There may be differences between this version and the published version. You are advised to consult the publisher's version if you wish to cite from it.

http://eprints.gla.ac.uk/138410/

Deposited on: 22 May 2017

Enlighten - Research publications by members of the University of Glasgow http://eprints.gla.ac.uk33640 


\title{
LIME BURNING IN CLAMP KILNS IN SCOTLAND'S WESTERN CENTRAL BELT: PRIMTIVE INDUSTRY OR SIMPLE BUT PERFECTLY ADEQUATE TECHNOLOGY?
}

\author{
$\square \mathrm{A} \square \mathrm{L} \square \mathrm{ISHO} \square \mathrm{CARM} \square \square \mathrm{C} \square \square \square \mathrm{CA}$ GARCIA $[$ ICHARD $\square \mathrm{O} \square \square \mathrm{S} \mathrm{A} \square \mathrm{D} \mathrm{D} \square \square \mathrm{CA} \square \mathrm{COO}$
}

\section{Contact details}

$\square \square$ eritus $\square$ ro essor $\square$ aul $\square$ isho $\square$

School o $\square$ Geogra $\square$ hical $\square \square$ arth Sciences

$\square$ ast $\square$ uad

$\square$ niversity o $\square$ Glasgow

Glasgow G12 8

$\square \square$ ail: $\square$ aul. $\square$ isho $\square .3 \square$ glasgow.ac.u $\square$

\section{Author Biographical Details}

The iirst three authors are a $\square$ iliated with the $\square$ niversity o $\square$ Glasgow. $\square$ A $\square$ L $\square$ ISHO geo $\square$ or $\square$ hologist $\square$ Honorary Senior Research $\square$ ellow in the School o $\square$ Geogra $\square$ hical and $\square$ arth Sciences $\square$ and $\square$ ellow o $\square$ the $\square$ niversity $\square$ has underta $\lceil$ en geo $\square$ or $\square$ hological wor $\square$ on archaeological e $\varangle$ cavations $\square$ including on cera $\square$ ic $\square$ iln ields in north central Thailand and on early ur $\square$ an sites in the $\mathrm{Me}\ulcorner$ ong delta in $\mathrm{Ca} \square \square$ odia. CARM $\square \square \mathrm{C} \square \square$ CA GARCIA is an A $\llbracket$ iliate Researcher in Archaeology in Glasgow $\square$ having co $\square \square$ leted her $\square \mathrm{hD}$ under the su $\square$ ervision o $\square$ RICHARD $\square \mathrm{O} \square \square$ S who is an archaeological geo $\square$ hysicist and Honorary Lecturer in Glasgows School o $\square$ $\mathrm{Hu} \square$ anities (Archaeology). $\mathrm{D} \square \square \mathrm{CA} \square \mathrm{CoO} \square$ is Senior Lecturer in Geogra $\square y$ at the Australian Catholic $\square$ niversity $\square$ Strath ield $\square \square$ ew South Wales $\square$ Australia $\square$ and or $\square$ erly $\square$ ost Doctoral Research Associate in the School o $\square$ Geogra $\square$ hical and $\square$ arth Sciences at the $\square$ niversity o $\square$ Glasgow. 


\section{Abstract}

$\mathrm{Li} \square$ e is a unda $\square$ ental co $\square \square$ onent in $\square$ any industrial $\square$ agricultural and che $\square$ ical $\lceil$ rocesses and is itsel $\square \square$ roduced $\square$ y an industrial $\square$ rocess $\square$ na $\square$ ely $\square$ the heating in ¿ilns (calcining $\square$ or $\square$ ore collo $\square$ uially $\square$ urning $)$ o $\square$ calciu $\square$ car $\square$ onate roc $\square$ or other car $\square$ onate $\square$ aterial. Research and literature on li $\square$ e $\square$ urning in Scotland $\square$ ased largely on li $\square$ e $\square$ roduction in Scotlands eastern Central $\square$ elt $\square$ are do $\square$ inated $\square$ y the view that li $\square$ e $\square$ urning in draw $\square$ ilns is the $\square$ aradig $\square$ or Scottish li $\square$ e $\square$ roduction. Other $\square$ arts o $\square$ Scotland $\square$ however $\square$ largely or co $\square \square$ letely ignored draw $\sqsubset$ ilns in avour o $\square$ si $\square \square$ ler cla $\square \square \square$ ilns $\square$ even in $\square$ a or industrial sites o $\square \mathrm{li} \square \mathrm{e} \square$ roduction. This $\square \mathrm{a} \square \mathrm{er}$ re $\square$ orts our $\square \mathrm{a} \square \square$ and ield $\square$ ased surveys in Scotlands western Central $\square$ elt $\square$ which clearly $\square$ oint to the enduring $\mathrm{i} \square \square$ ortance and al $\square$ ost e $\square$ clusive use o $\square$ cla $\square \square \square$ ilns in that areas historical li $\square \mathrm{e} \llbracket$ urning industry.

पøYWORDS: Clamp kiln; lime; draw kiln; lime burning 
Li $\square$ e is $\square$ roduced $\square$ y heating ( $\square$ urning $\square$ or calcining) calciu $\square$ car $\square$ onate (li $\square$ estone $\square$ $\square$ ar $\square$ le $\square \square$ arine shells) to $\square 900 \triangle$ C. $^{1}$ Modern $\square$ roduction is industrial in scale $\square$ whereas $\square$ historically $\square$ roduction technology ranged ro $\square \mathrm{s} \square$ all single use Sow $\square$ ilns $\square$ to $\mathrm{s} \square$ all and $\square$ ediu $\square$ si ed $\square$ ulti use cla $\square \square \square$ ilns $\square$ large cla $\square \square \square$ ilns with in rastructure $\square$ and stone $\square$ uilt $\llbracket$ continuously o $\square$ erating draw $\sqsubset$ ilns (also called sha $t$ tilns). ${ }^{2}$ Sow and cla $\square \square$ ¿ilns are relatively si $\square \square$ le $\square$ elongated $\square$ sha $\square$ ed e $\square \square$ ay $\square$ ents or $\square$ ore circular (horseshoe $\$ sha $\square$ ed) $\square$ its ( $\square$ igure 1$) \square$ elongated $\square$ its that are o $\square$ en at $\square$ oth ends have also $\square$ een o $\square$ served at one site. ${ }^{3}$ Li $\square$ estone and uel $\square$ generally coal $\square \square$ ut wood and $\sqsubset$ eat were also used $\square$ were interllayered in the iln and the Uel ignited. ${ }^{4}$ The heat calcined the li $\square$ estone $\left(\mathrm{CaCO}_{3}\right)$ to $\square$ uic $\square \mathrm{li} \square \mathrm{e}(\mathrm{CaO}) \square \mathrm{l} \square$ erating car $\square$ on dio $\square$ ide $\left(\mathrm{CO}_{2}\right)$. The relative $\square$ ro $\square$ ortions o $\square$ uel to li $\square$ estone $\square$ in the case o $\square$ coal $\square$ one $\square$ art o $\square$ coal to generally two to our $\square$ arts o $\square \mathrm{li} \square$ estone $\square$ and occasionally to one $\square$ art o $\square \mathrm{li} \square$ estone $\square$ all de $\sqsubset$ ending on the ty $\sqsubset$ es and $\square$ ualities o $\square$ the coal and li $\square$ estone $\square \square$ ean that $\sqsubset$ ilns are $\square$ ost sensi $\square$ ly located at the source o $\square$ the li $\square$ estone. $\square$ This locational orce is rein orced $\square$ y the act that a tonne o $\square \mathrm{li} \square$ estone $\square$ roduces hal $\square$ a tonne o $\square \mathrm{li} \square$ e. In the draw $\square$ iln (also so $\square$ eti $\square$ es called a shat $\square$ iln) $\downarrow$ the charge (li $\square$ estone and coal) was loaded continuously at the to $\square$ o $\square$ the iln $\square$ ot and $\square$ oved down through the $\square$ ot as the $\mathrm{li} \square$ estone was calcined and the $\square$ uic $\square \mathrm{li} \square$ e was drawn o $\square$ at the $\square$ ase o $\square$ the $\square$ ot. Draw $\square$ ilns could thus o $\square$ erate continuously or long $\square$ eriods. In a cla $\square \square$ iiln $\square$ the contents o the $\square$ iln were covered over (cla $\square \square$ ed) to control the $\square$ urning. ${ }^{6}$ Ater the cla $\square \square$ Giln cooled the $\square$ uic $\square \mathrm{li} \square$ e was un $\square$ ac $\square$ ed. The li $\square$ e $\square$ roduced $\square$ y $\square$ oth styles o $\square$ ¿ilns could $\square$ e trans $\square$ orted away as either $\square$ uic $\square \mathrm{li} \square$ e or sla $\square$ ed li $\square$ e ( $\square$ y the addition o $\square$ water to the $\square$ uic $\square \mathrm{li} \square \mathrm{e}$ ).

$\mathrm{Li} \square$ e has $\square \mathrm{o} \square$ course $\square$ een used or $\square$ illennia in $\square$ uilding $\square$ lastering and li $\square$ e washing $\square$ and there are re $\square$ orts that li $\square$ e ro $\square \mathrm{Ca} \square \square$ sie $\square$ one o $\square$ our areas o $\square$ interest here $\square$ was used in $\square$ uilding Glasgow $\square$ s edieval Cathedral $\square$ which was consecrated in the late 12 th century. ${ }^{7}$ More recently $\square \mathrm{li} \square$ ing o $\square$ agricultural soils was critical to Scotland S agricultural revolution o the 18th and 19th centuries. Indeed $\square \mathrm{S} \square$ out and $\square$ enton have noted that $\llbracket$ erha $\square$ s the $\square$ ost $\mathrm{i} \square \square$ ortant o the innovations in Scottish agriculture $\square \mathrm{S} \square$ rang $\llbracket$ ro $\square$ the reali $\square$ ation at the turn o $\square$ the seventeenth century o $\square$ the value o $\square \mathrm{i} \square$ ing ${ }^{8}{ }^{8}$ Hay recently reiterated the sa $\square \mathrm{e} \square$ oint and li $\square$ ing o $\square$ ields re $\square$ ains i $\square \square$ ortant or land $\square$ anage $\square$ ent in Scotland. ${ }^{9}$ Agricultural li $\square$ ing is $\mathrm{i} \square \square$ ortant in 
northern $\square$ ritain $\square$ ecause the regions high rain all generally results in acidic $\square$ oten $\sqsubset$ oorly structured soils $\square$ and li $\square$ ing $\square$ oth neutralises the soil $\mathbf{s}$ e $\square$ cess acidity and $\mathrm{i} \square \square$ roves the soils structure. ${ }^{10} \mathrm{Li} \square \mathrm{e}$ is also an $\mathrm{i} \square \square$ ortant $\mathbb{t u} \square$ in $\square$ any industrial $\square$ rocesses $\square$ and de $\square$ and or $\mathrm{li} \square$ e increased once the industrialisation o $\square$ western Scotland was under way in the late 18th century and develo $\square$ ed $\square$ uch $\square$ ore $\mathrm{e}$ tensively in the 19 th century.

The earliest agricultural li $\square$ ing in Scotland $\square$ ay date ro $\square$ at least the early 17th century and li $\square$ e was de $\square$ onstra $\square$ y $\square$ eing $\square$ roduced in Scotlands western Central $\square$ elt $\square$ y this ti $\square$ e. ${ }^{11} \square$ elsches $\square$ re $\square$ ort on agriculture in Stirlingshire $\square$ the historical location o $\square$ our study area $\square$ con $\operatorname{ir} \square$ s the $\square$ ore wides $\square$ read use o $\square$ li $\square$ e in agriculture $\square \mathrm{y}$ the $\square \mathrm{id} 18$ th century. ${ }^{12}$ The incor $\square$ oration o $\square$ a distinctive elongated rectangular side e $\square \square$ ay $\square$ ent (inlet) on the south $\square$ an $\square$ o $\square$ the $\square$ orth and Clyde Canal to service li $\square$ e draw $\square$ ilns a $\square$ out $1 \square$ west o $\square$ Wynd ord Loc $\square$ ust outside the southern $\square$ oundary o $\square$ Stirlingshire $\square$ also con $\operatorname{ir} \square \mathrm{s}$ that li $\square \mathrm{e} \square$ roduction was well esta $\square$ lished in that area $\square$ y $1773 \square$ when water was irst let into that $\square$ art o $\square$ the canal. ${ }^{13}$ A $\square$ lan in the $\square$ niversity o $\square$ Glasgow Archives $\square$ centred on the study area and dated 177 $\square \square$ annotates the $\square$ an $\square$ ier $\square$ ar $\square$ la $\square$ el in $\square$ aldernoc $\square$ with Coall $\square$ Li $\square$ e.$^{14}$ Ross S $1777 \square \mathrm{a} \square \square$ ing o $\square$ Coal $\square$ and $\operatorname{Li} \square \mathrm{e} \square$ at Culloch $\square \mathrm{a}$ ew $\square$ ilo $\square$ etres to the west o the $\square$ resent study area $\square$ con ir $\square \mathrm{s} \square \mathrm{id} \square$ to late 18th century $\square$ roduction o $\square \mathrm{li} \square \mathrm{e}$ in that area $\square$ and an 180 $\square \operatorname{ar} \square \square$ lan or the Dougalston $\square$ state de $\square$ icts two $\square$ sha $\square$ ed cla $\square \square \square$ ilns ( $\square$ ills) on Long auld $\square$ ar $\square$ near Culloch. ${ }^{1 \square}$ An 1812 re $\sqsubset$ ort on Stirlingshire con ir $\square \mathrm{s}$ the wides $\square$ read use o $\square \mathrm{i} \square \mathrm{e} \square \mathrm{y}$ the irst decade o the 19th century. ${ }^{16}$

So the $\square$ roduction and use o $\square \mathrm{li} \square \mathrm{e}$ in Scotland were well esta $\square$ lished $\square \mathrm{y}$ the end o the 18th century. In $\square \operatorname{ar}\lceil$ ed contrast to the situation or Yor $\square$ shire $\square$ however $\square$ the technology o $\square$ Scotland S early li $\square \mathrm{e} \square$ roduction re $\square$ ains $\mathrm{S} \square$ arsely docu $\square$ ented. ${ }^{17}$ $\square$ onetheless $\square$ the literature continues to e $\square \square$ hasise $\square$ al $\square$ ost e $\square$ clusively $\square$ large $\square$ asonry $\square$ uilt draw $\square$ ilns. ${ }^{18}$ Indeed $\square$ Coulls recent review re $\square$ eated the co $\square \square$ on $\mathrm{o} \square$ servation that the $\square$ est surviving evidence o $\square \mathrm{l} \square \mathrm{e} \square$ roduction in Scotland is the $\square$ attery o $\square$ large li $\square$ e $\square$ ilns in Charlestown $\square \square \mathrm{ie} .^{19}$ Li $\square$ ewise $\square$ considera $\square$ le $\square$ ro $\square$ inence is given to S inners wor $\square$ on large draw $\square$ ilns in the Lothians to the unhel $\square$ ul (and ina $\square$ ro $\square$ riate) e tent that the Lothians is thought o $\square$ as $\$ so $\square$ ehow the cradle o the

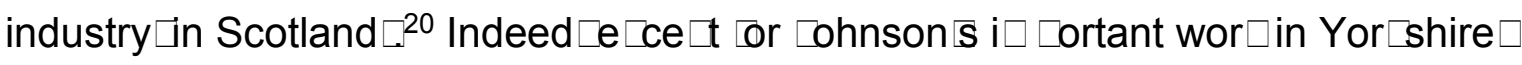
and the crucial $\square \square$ ut $\square$ erha $\square$ s not widely $\square$ nown $\square$ wor $\square$ in Scotland o $\square \square$ is $\square$ et and Mac $\square$ ay $\square \square$ u lished wor $\square$ in $\square$ ritain $\square$ even the very local $\square$ generally ocuses on 
$\square$ asonry $\square$ uilt draw $\square$ ilns. ${ }^{21}$ This ocus on draw ilns is inconsistent with the wides $\square$ read re $\square$ ains o $\square$ cla $\square \square$ Cilns in Scotland. ${ }^{22}$ Here $\square$ we e $\square$ a $\square$ ine li $\square$ e $\square$ urning in ScotlandS western Central $\square$ elt $\square$ with a ocus on the $\square$ arishes o $\square \square$ aldernoc $\square$ and $\mathrm{Ca} \square \square$ sie in the area now covered $\square$ y the 21st century local govern $\square$ ent area o $\square \square$ ast Dun $\square$ artonshire $\square \square$ ut or $\square$ erly in the $\square$ id 19 th century county o $\square$ Stirlingshire.

ST $\square$ DY AR $\square \mathrm{A}$

The western Central $\square$ elt o $\square$ Scotland around Glasgow was the heartland o $\square$ heavy industrialisation in Scotland $\square$ which acco $\square \square$ anied $\square$ and then su $\square \square$ lanted the growth o $\square$ weaving $\square$ cloth $\square$ leaching and $\square$ rinting. The e traction and $\square$ rocessing o $\square$ the western Central $\square$ elt s rich endow $\square$ ent o $\square$ coal and ironstone under $\square$ inned the develo $\square \square$ ent o $\square$ iron and steel $\square$ roduction and heavy engineering $\square$ including the shi $\square \square$ uilding or which Glasgow and neigh $\sqsubset$ ouring areas $\square$ eca $\square$ e noted. Scotlands Central $\square$ elt coal and ironstone are hosted in a ritt valley down aulted $\square$ etween the Southern $\square \square$ lands to the south and the Scottish Highlands to the north. The sedi $\square$ ents in illing this $\square$ a or sedi $\square$ entary $\square$ asin $\square$ the Midland Valley $\square$ also include li $\square$ estone $\square$ as well as econo $\square$ ically $\mathrm{i} \square \square$ ortant sandstone $\square$ ireclay $\square$ and oil shale. In $\square$ any $\square$ laces the geological se $\square$ uence consists o $\square$ coal $\sqsubset$ eds (sea $\square$ s) that are inter $\llbracket$ edded (interstratilied) with high $\square$ uality li $\square$ estone and ironstone $\square$ acilitating relatively easy e $\leftarrow$ traction o $\square$ these resources. ${ }^{23}$ The $\square$ ey geological unit targeted $\square$ y the li $\square \mathrm{e} \square$ urners in $\square$ oth $\square$ aldernoc $\square$ and $\mathrm{Ca} \square \square$ sie were the Hurlet Li $\square$ estone and Coal. ${ }^{24}$ There has $\square$ een $\square$ uch change to geologucal no $\square$ enclature over the last century and in the $\mathrm{Ca} \square \square$ sie area the target has $\square$ reviulsy $\square$ een $\square$ nown as the Ca $\square \square$ sie Main Coal and $\mathrm{Li} \square$ estone. $^{2} \square$ In Ca $\square \square$ sie $\square$ a shale sandwiched $\sqsubset$ etween the coal and the li $\square$ estone was used or $\square \mathrm{a} \square$ ing alu $\square \square$ which $\mathrm{e} \square$ lains why the Ca $\square \square$ sie Alu $\square$ Wor $\square \mathrm{s} \square \square$ art o $\square$ the largest alu $\square$ wor $\square$ s in the $\square$ nited $\square$ ingdo $\square \square$ also hosted li $\square$ e $\square$ ilns (see $\square$ elow). ${ }^{26}$ traction o the coal and li $\square$ estone or the $\square$ roduction o $\square$ li $\square$ e is $\square$ ade $\square$ ore di $\square$ icult $\square$ however $\square$ y aulting o $\square$ these de $\square$ osits. This aulting $\square$ eans that coal and li $\square$ estone that were originally continuous across a large area $a \square r u$ tly cut out at a ault $\square$ where one $\square$ loc $\square$ o $\square$ the $\square$ arths crust has $\square$ een $\square$ oved u $\square$ or down relative to another. Thus $\square$ in $\square$ any localities $\square$ ty $\square$ iied $\square \mathrm{y} \square$ arts o $\square$ the western Midland Valley se $\square$ uence the coal and li $\square$ estone that were wor $\square$ ed or li $\square$ e $\square$ urning are at di $\square$ erent de $\square$ ths in di $\square$ erent $\square$ loc $\square$ s o $\square$ ground. Wor $\square$ a $\square$ le coal and li $\square$ estone are e $\square$ ectively 
$\mathrm{a} \square$ sent $\operatorname{ro} \square$ so $\square \mathrm{e} \square$ loc $\square$ s o $\square$ ground $\square$ either $\square$ ecause the geological units containing these $\square$ aterials have $\square$ een aulted $\mathrm{u} \square$ and eroded away $\square$ or they have $\square$ een down $\square$ aulted and are too dee $\square$ to have $\square$ een wor $\_$ed econo $\square$ ically and/or saely with 17 th $\square$ and 18th century technology. As well $\square$ volcanic intrusions (dy $\lceil$ es and sills) locally $\square$ a $\ulcorner$ ed and/or $\square$ urned the li $\square$ estone and coal $\square$ co $\square \square$ ro $\square$ ising the e $\square$ traction and use o $\square$ these $\square$ aterials.

\section{DATA A $\square \mathrm{D} M \square T H O D S$}

Ordnance Survey (OS) $\square$ id 19 th century irst edition $\square \mathrm{a} \square \mathrm{s}$ o $\square$ Scotland S Central $\square$ elt $\square$ at scales o $\square 6$ inches to the $\square$ ile and 1:2 $\square 00$ (collo $\square$ uially called $2 \square$ inches to the $\square$ ile) $\square$ are a valua $\square$ le resource or understanding historical li $\square$ e $\square$ urning. OS used $\square$ any di $\square$ erent sy $\square \square$ ols to $\square \mathrm{a} \square$ li $\square$ e $\square$ ilns $\square$ ut this a $\square \square$ arently large nu $\square\lceil$ er o $\square$ sy $\square \square$ ols is easily si $\square \square$ li iled into two $\square$ road classes $\square$ the cla $\square \square$ iiln and the draw $\square$ iln (sha t $\square$ iln). ${ }^{27}$ Cla $\square \square$ cilns are generally re $\square$ resented $\square$ y a $\square$ sy $\square \square$ ol or an o $\square$ en ended

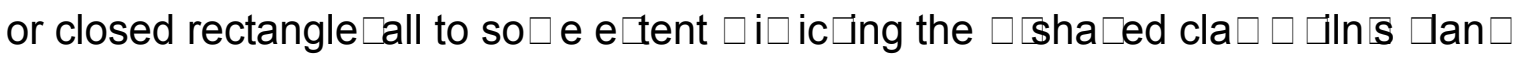
view $\square$ or $\square$ hology ( $\square$ igure 1 ). The $\square$ ore co $\square \square$ le $\square$ technology o the draw $\square$ iln $\square$ in which a stone $\square$ uilt structure encloses an internal $\sqsubset$ iln $\square$ ot or $\square$ ots $\square$ is $\square \mathrm{a} \square$ ed either using a circle $\square$ so $\square$ eti $\square$ es with a $\square$ lac $\square$ dot on the circles circu $\square$ erence $\square$ or in a $\square$ ore ¿ictogra $\square$ hic style $\square$ with a circle re $\square$ resenting the $\square$ iln $\square$ ot $\square$ within a surrounding $\square$ olygon that indicates the edges o $\square$ the $\square$ asonry structure that encases and su $\square$ orts the $\sqsubset$ ot. $^{28}$

As $\square$ art o $\square$ a wider assess $\square$ ent o $\square$ the distri $\square$ ution o $\square$ the li $\square$ e industry across Scotland in the $\square \mathrm{id}$ 19th century $\square$ every $\square \mathrm{a} \square \square$ ed occurrence o $\square \mathrm{li} \square \mathrm{e} \sqcap$ ilns or $\mathrm{li} \square$ ewor $\square \mathrm{s}$ on OS 1st edition 1:10 $\square 60$ scale (si $\square$ inch) $\square \mathrm{a} \square \mathrm{s}$ o $\square$ central Scotland $\square$ covering $\square$ $\square$ roadly ro $\square$ west to east (and using the $\square$ id 19 th century county na $\square$ es) $\square$ the Counties o $\square$ Ayrshire $\square$ Ren $r$ rewshire $\square$ Dun $\square$ artonshire $\square$ Lanar $\llbracket$ shire $\square$ Stirlingshire $\square$ Linlithgowshire (West Lothian) $\square \square$ din $\square$ urghshire (Midlothian) $\square$ Haddingtonshire ( $\square$ ast Lothian) $\square \square$ erwic $\square$ shire $\square \square$ erthshire $\square$ Clac $\square$ annanshire $\square$ and $\square$ ieshire $\square \square$ inross $\square$ shire $\square$ has $\square$ een docu $\square$ ented. ${ }^{29}$ All 487 sheets that $\square \mathrm{a} \sqsubset \mathrm{e} \mathrm{u} \square$ this coverage were e $\square$ a $\square$ ined $\square$ y syste $\square$ atically $\square$ oving an A4 si $\square$ ed window $\square$ west to east across each sheet $\square$ on successive west east lines down the sheet. $\square$ ach li $\square$ e $\square$ iln or li $\square$ ewor $\square$ s was noted within that window $\square$ assisted $\square$ y a $\square$ agni ying glass as necessary. The $\square \mathbf{a} \square$ ed $\square$ iln sy $\square \square$ ols were recorded $\square$ as well as the location o $\square$ each li $\square \mathrm{e} \square$ iln or 
li $\square$ ewor $\square$ s $\square$ to a $\square$ recision o $\square \square$ seconds in latitude and longitude $\square$ using the latitude and longitude on the $\square \mathrm{a} \square$ sheets $\square$ argins. Other in or $\square$ ation related to the industrial activity was also recorded $\square$ including the $\square$ resence o $\square \square$ uarries $\square \square$ ines $\square$ tra $\square$ ways $\square$ train lines $\square$ and so on. We then wor $\_$ed our way through all 487 sheets a second $\mathrm{ti} \square \mathrm{e} \square$ chec $\square$ ing the $\square \mathrm{a} \square$ or the accuracy o $\square$ the recorded in or $\square$ ation as well as $\square \mathrm{o} \square$ ing

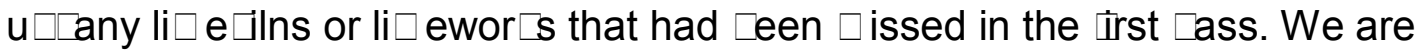
con ident that we have located virtually all o $\square$ the li $\square$ e related eatures $\square \mathrm{a} \square \square$ ed on these 487 sheets.

Here the $\square \mathbf{a} \square$ data covering the 19th century $\square$ arishes o $\square \square$ aldernoc $\square$ and $\mathrm{Ca} \square \square$ sie in the $\operatorname{or} \square$ er County o $\square$ Stirlingshire are used to docu $\square$ ent each OS $\square$ $\square \mathrm{a} \square \square$ ed occurrence o $\square \mathrm{i} \square \mathrm{e} \square$ ilns or li $\square$ ewor $\square$ s ( $\square$ igure 2). A chec $\square \mathrm{o} \square$ OS 1st edition $2 \square$ inch $\square \mathrm{a} \square \mathrm{s}$ o $\square$ the area con $i \mathrm{r} \square$ ed that the sa $\square \mathrm{e}$ illns have $\square$ een $\square \mathrm{a} \square \square$ ed on $\square$ oth series and that the $2 \square$ inch $\square \mathrm{a} \square$ s do not contain any $\square$ ore data on li $\square \mathrm{e}$ ilns than do the 6 inch $\square \mathrm{a} \square \mathrm{s} \square$ although the $2 \square$ inch $\square \mathrm{a} \square$ s o ten $\square$ ore e $\square$ licitly $\square \mathrm{a} \square$ and la $\square$ el $\square$ ine shats $\square$ which $\square$ ay $\square \mathrm{e} \square \mathrm{a} \square \square$ ed $\square$ ut unla $\square$ elled on the corres $\square$ onding 1st edition 6 inch $\square \mathrm{a} \square$ s. These $\square \mathrm{a} \square \square$ ing data were su $\square \square$ le $\square$ ented $\square$ y written re $\square$ orts ro $\square 1796$ and $1812 \square$ the $1841 \square 18 \square 1 \square 1861$ and 1871 censuses $\square$ and the Old and $\square$ ew Statistical Accounts o the $\square$ arishes o $\square \square$ aldernoc $\square$ and $\mathrm{Ca} \square \square$ sie. $^{30} \square$ tensive ield chec $\square$ ing and $\square \mathbf{a} \square$ ing o $\square$ un $\square \mathbf{a} \square \square$ ed $\square$ ilns $\square$ guided initially $\square$ y OS $\square \mathbf{a} \square$ ing $\square$ ut then ranging $\square$ ore widely $\square$ were also underta $\lceil$ en.

Gradio $\square$ eter surveys o $\square$ the South Craigend and $\square$ oghall $\square$ iln ijelds were underta $\ulcorner$ en using dual and single $\pitchfork u\lceil$ gate gradio $\square$ eter $\square$ artington 601 instru $\square$ ents. $\operatorname{Re} \sqsubset$ eated $20 \square 20 \square$ survey grids $\square$ tied into the $\square$ ritish $\square$ a $\square$ grid using a Leica di $\square$ erential G $\square$ S $\square$ were laid out at $\sqsubset$ oth sites using $\square$ ar $\square$ ed ro $\square$ es. The sa $\square \square$ ling used a traverse s $\square$ acing o $\square 0 . \square \square$ and a $0.12 \square \square$ sa $\square \square$ ling interval $\square$ with a $\square$ ig $\square$ ag survey $\square$ ode. $\square$ orty two standard $20 \square 20 \square$ grids were surveyed at $\square$ oghall and our standard grids at South Craigend $\square$ ollowing $\square$ nglish Heritage s reco $\square \square$ endations or $\square$ agneto $\square$ eter survey in archaeological $\square$ ractice. ${ }^{31}$

The $\square \mathbf{a} \square$ ing o $\square$ ilns also located other in rastructure $\square$ including roads ro $\square$ the iln ields or $\square$ we assu $\square \mathrm{e}$ the carriage o $\square \mathrm{i} \square \mathrm{e}$ or on trans $\square$ ort to destinations urther a iield. A rectangular $\square$ stone lined tan $\square$ at the to $\square \mathrm{o} \square$ the South Craigend $\mathrm{li} \square \mathrm{e}$ road in $\square$ aldernoc $\square$ is in illed with a $\square$ out $0 . \square \square$ o $\square$ organic rich sedi $\square$ ent overlying a thic $\square$ clay seal on the $\square$ otto $\square$ o $\square$ the tan $\square$. We cored this sedi $\square$ ent with a Russian corer to $0.7 \square$ de $\square$ th $\square$ and used $\square$ rays o the core and standard sedi $\square$ entological 
analyses to identi y the $\square$ ase o $\square$ the $\square$ ost $\square$ a andon $\square$ ent sedi $\square$ ent in ill over the $\square$ asal seal. The cored sedi $\square$ ent was sa $\square \square$ led at $2 \square \square \square$ de $\square$ th intervals $\square$ e $\square$ ce $\square$ t or three 0. $\square \square$ sa $\square \square$ ling intervals $\square$ and analysed $\square$ y IC $\square$ MS or total lead ( $\square \square$ ) at the Scottish $\square$ niversities $\square$ nviron $\square$ ental Research Centre (S $\square \square \mathrm{RC}$ ) $\square \square$ ast $\square$ il $\square$ ride $\square$ using standard $\mathrm{S} \square \square \mathrm{RC} \square$ rocedures and $\square$ rotocols. ${ }^{32}$ These total lead contents were used to esti $\square$ ate the $\square$ asal age o $\square$ the sedi $\square$ ents in illing $\square$ as an esti $\square$ ate o $\square$ the age o $\square$ a $\square$ andon $\square$ ent o the tan $\square$ and the onset o $\square$ its in illing as the li $\square$ e industry wound down at South Craigend. This de $\square$ th $\square$ ro ile o $\square$ total $\square \square \mathrm{a} \square$ ove the seal in the South Craigend tan $\square$ was then wiggle $\square$ atched to $\square$ ar $\square$ er et al. s ${ }^{210} \square \square$ dated $\square$ roile o $\square$ total $\square \square$ ro $\square$ Loch Lo $\square$ ond $\square \mathrm{a} \square$ out $2 \square \square \square \mathrm{W}$ o $\square$ the $\square$ aldernoc $\square$ area. ${ }^{33}$ We carried out the wiggle $\square$ atching in order (i) to date the South Craigend $\square$ roile $\square$ and in $\square$ articular (ii) to $\square$ rovide a $\square$ asal age or the in ill sedi $\square$ ent and hence a suggested age o $\square$ the onset o $\square$ the decline o $\square$ the industry at South Craigend (see $\square$ elow). The dated Loch Lo $\square$ ond $\square$ roile o $\square$ total $\square \square$ is in e $\square$ ect a record through ti $\square$ e o $\square$ industrial $\square$ ollution in the West o $\square$ Scotland. It has already $\square$ een used success $u l l y$ to date sedi $\square$ ents in a $\square$ ill da $\square$ in $\square$ aldernoc $\square$ in that case $\square$ y $\square$ atching $\square$ y eye the dated $\square$ ea $\square$ s and troughs in the Loch Lo $\square$ ond $\square \square$ record to the $\square$ ea $\square$ s and troughs in the $\square$ ill da $\square$ sedi $\square$ ent record o $\square$ total $\square \square^{34}$ Here we used a $\square$ ore rigorous wiggle $\square$ atching a $\square \square$ roach derived ro $\square$ radiocar $\square$ on dating. ${ }^{3}$

$\mathrm{LIM} \square \square \square \mathrm{R} \square \mathrm{I} \square \mathrm{G} \mathrm{I} \square \mathrm{TH} \square \square \mathrm{ALD} \square \mathrm{R} \square \mathrm{OC} \square \mathrm{AR} \square \mathrm{A}$

$\mathrm{S} \square$ ATIAL DISTRI $\square \square$ TIO $\square$

When OS 1st edition and lield data are co $\square$ ined $\square$ the $\square$ aldernoc $\square$ area $\square$ co $\square \square$ rising $\square$ aldernoc $\square \square$ arish and the $\mathrm{i} \square \square$ ediately adacent $\square$ arts o $\square$ the neigh $\square$ ouring $\mathrm{Ca} \square \square$ sie $\square$ arish ( $\square$ igure 2) $\square$ has the re $\square$ ains o $\square \square$ ore than $1 \square 0$ li $\square$ e cla $\square \square$ iilns (Ta $\square$ le 1$) \square$ there are no draw illns in the area. That total nu $\square \square$ er o $\square$ cla $\square \square$ iilns is $\square$ ore than dou $\square$ le the nu $\square \square$ er $\square \mathrm{a} \square \square$ ed $\square \mathrm{y}$ OS.

There a $\square \square$ ear to $\square$ e two $\square$ ain $\square$ atterns o $\square$ iln organisation in $\square$ aldernoc $\square$ : (i) clusters and/or lines o $\square$ ilns ad acent to each other $\square$ oten in orderly arrange $\square$ ents ( $\square$ igures $3 \square 4 \square \square \square \square$ and 7 ) $\square$ and (ii) single $\square$ ilns away ro $\square$ the $\square$ ain organised clusters (e.g. $\square$ Grou $\square 8$ ilns on $\square$ igure $\square$ A). All li $\square$ e wor $\square$ ings are located on occurrences o $\square$ 
li $\square$ estone and coal in outcro $\square$ or at shallow de $\square$ th $\square$ with the discontinuous nature o $\square$ the $\square$ a or concentrations o $\square \mathrm{li} \square \mathrm{e}$ wor $\square$ ings across the area $\square$ eing related to the aulting and disru tion o $\square$ the $\square$ eds. All clusters o $\square \square$ ulti $\square$ le $\square$ ilns are grou $\square$ ed near or around $\square$ uarries or $\square$ ine entrances $\square$ as at $\square$ oghall (Ta $\square$ le $1 \square 1 \square \square$ igure 3 ) $\square$ Hole (Ta $\square$ le $1 \square 3 \square \square$ igure 4) South Craigend (Ta $\square$ le $1 \square \square \square \square$ igure $\square$ ) $\square \square$ lairs $\square$ aith Trig $\square$ oint (Ta $\square$ le 1 $\square$ 6 $\square$ igure 6) $\sqsubset$ and Glenwynd (Ta $\square$ le $1 \square 7 \square \square$ igure 7). Indeed $\square$ no li $\square$ e $\square$ ilns are ar ro $\square$ a $\square$ ine or $\square$ uarry $\square$ even slightly isolated individual $\square$ ilns $\square$ such as the individual Grou $\square 8$ ilns at South Craigend ( $\square$ igure $\square$ ). Where $\square$ ilns and $\square$ ine were se $\square$ arated $\square$ even only $\square$ y a short distance $\square$ tra $\square$ ways on narrow linear elevated ridges oten connected $\sqsubset$ iln and slightly distant $\square$ ine (e.g. $\square$ Hole $\square$ (igure 4 $\square \square$ lairs $\square$ aith Trig $\square$ igure 6). Overall $\square$ then $\square$ the $\square$ attern is that $\square$ aldernoc $\square$ Cilns $\square \square$ e they clustered or individual $\square$ were essentially always close $\square$ or well connected $\square$ to $\square$ ines.

$\mathrm{O} \square \square \mathrm{RATIO} \square \mathrm{O} \square \mathrm{TH} \square \square \mathrm{ALD} \square \mathrm{R} \square \mathrm{OC} \square \mathrm{CLAM} \square \square \mathrm{IL} \square \mathrm{S}$

The clusters and/or lines o $\square$ cla $\square \square \square$ ilns $\square$ resu $\square \mathrm{a} \square$ ly acilitated a cycle o $\square$ loading $\square$ $\square$ urning $\square$ cooling $\square$ and unloading the $\square$ ilns in se $\square$ uence $\square$ with each $\sqsubset$ iln in the cluster $\lceil$ eing at a di $\square$ erent $\square$ oint in the cycle. The $\square$ ilns ad acent to $\square$ ine entrances would $\square$ resu $\square \mathrm{a} \square$ ly have $\square$ een charged with li $\square$ estone and coal directly ro $\square$ the $\square$ ines $\square$ a ter $\square$ rea $\square$ ing o $\square$ the li $\square$ estone and coal to a $\square \square$ ro $\square$ riately si $\square$ ed rag $\square$ ents $\square$ whether the cilns were individual $\square$ ilns with adacent $\square$ ine sha ts $\square$ or cluster or $\square$ an $\square$ s o $\square$ ilns adacent to a shatt (e.g. $\square$ Glenwynd $\square$ Ta $\square$ le $1 \square 7 \square \square$ igure 7 ).

A $\square$ ine $\mathrm{a} \square$ andon $\square$ ent $\square$ lan that includes the South Craigend li $\square$ e $\square$ ilns and is $\square$ ased on OS 1st edition $\square \mathrm{a} \square$ ing shows the $\sqsubset$ ilns clustered around the $\square$ ine entrance ro $\square$ where the $\square$ ilns would $\square$ resu $\square \mathrm{a} \square$ ly have $\square$ een serviced $\square$ y a tra $\square$ way $^{36}$. The $\square$ lan indicates that the $\square$ ine $\square$ eing a $\square$ andoned was wor $\square$ ing $\square$ lac $\square$ $\square$ anded ironstone $\square$ ut the e $\square$ licit identi ication o $\square$ areas o $\square$ solid li $\square$ estone $\square$ and solid li $\square \mathrm{e} \sqsubset$ on the $\square$ lan con ir $\square \mathrm{s}$ that the $\square$ iners were also e $\square$ tracting (or had $\square$ reviously e $\leftarrow$ tracted) coal and li $\square$ estone. ${ }^{37}$ The coal and li $\square$ estone would have ed the $\square$ ilns clustered around the $\square$ ine $\mathbf{S} \square$ ain entrance $\square$ which is still visi $\square$ le as a degraded (in illed) gully

The gradio $\square$ eter survey o $\square$ the South Craigend $\square$ ilns indicates su $\square$ surace structures a $\square$ arently $\square$ resent $\sqsubset$ eneath and $\sqsubset$ etween $\sqsubset$ ilns ( $\square$ igure $\square \square$ ). We inter $\square$ ret these structures $\square$ which are yet to $\square$ e e $\sqsubset$ cavated $\sqsubset$ to $\square$ e su $\square$ sur ace $\square$ lu $\square \square$ ing $\sqsubset$ to aid 
the o $\square$ eration o $\square$ the $\square$ iln $\square \square$ erha $\square$ s $\square$ eing si $\square$ ilar to the ty $\sqsubset$ es re $\square$ orted $\square$ y Radcli $\square$ e in $\lceil$ eat $\square$ ired cla $\square \square$ ilns in early 19th century Scotland and $\square$ y $\square$ ohnson ro $\square$

e $\square$ cavations in Yor $\square$ shire ${ }^{38}$. Car $\square$ on dio $\square$ ide $\square$ the $\square$ a or $\square$ y $\square$ roduct in calcining li $\square$ estone $\square$ had to $\square$ e vented away or else it would have $\square$ uenched the la $\square$ e. Thus $\square$ it was essential that a $\square$ iln $\square$ e vented $\square$ while also not allowing too $\square$ uch o $\square$ ygen to the Ia $\square \mathrm{e} \leftarrow$ which could have over heated and vitrilied the li $\square$ estone. A $\square$ ile o $\square$ iln waste ad acent to the South Craigend $\square$ ilns ( $\square$ igure $\square$ A) includes lu $\square \square$ s o $\square$ such vitri ied and over coo $\left\ulcorner\right.$ ed $\_$stone.

$\mathrm{OTH} \square \mathrm{R} I \square[\mathrm{RASTR} \square \mathrm{CT} \square \mathrm{R} \square$

As well as tra $\square$ ways $\square$ in rastructure in the $\square$ aldernoc $\square \mathrm{li} \square$ e industry included now $\square$ $\mathrm{a} \square$ andoned lanes/roads that connected the $\square$ iln ields on the higher ground o $\square$ the $\mathrm{u} \square$ land $\square$ uirs ( $\square$ oors) to trans $\square$ ort routes on lower ground ( $\square$ igures 8 and 9 ). $\square$ ach $\mathbb{i} i$ e road $\square$ is now lan $\lceil$ ed on either side $\square$ y a line o $\square$ straggly hawthorn trees that have grown $\square$ iro $\square$ the hedges that lined the roads. The roads were well $\square$ ade with $\square$ uilt $\mathrm{u} \square \mathrm{e} \square \square$ an $\square$ ents and $\square$ asonry lined cuttings to $\square$ aintain the gradients or ( $\square$ resu $\square \mathrm{a} \square \mathrm{y}$ ) horse and cart. The detail o the construction o $\square$ these roads awaits urther investigation $\square$ ut they have so ar revealed no evidence o $\square$ tra $\square$ ways. It is $\mathrm{s} \square$ eculated that the rectangular $\square \square 1 \square$ dee $\square$ stone lined tan $\square$ at the to $\square \mathrm{o} \square$ the South Craigend li $\square$ e road ( $\square$ igure $\square$ ) $\square$ rovided water or horses at the to $\square$ o $\square$ a long cli $\square \square$. Running water at the to $\square$ o the cli $\square \square$ would have $\square$ et that need or the Glenwynd $\mathrm{li} \square$ e road $\square$ and the Langshot li $\square$ e road $\measuredangle$ the least stee $\square$ o the three li $\square$ e roads $\square$ had a rectangular tan $\square$ at the $\square$ otto $\square$ o $\square$ the hillslo $\square$ e that the road serves $\square$ as evidenced on OS 1st edition $2 \square$ inch $\square \mathrm{a} \square$ ing.

The li $\square$ e roads were or trans $\square$ orting the li $\square$ e to lower elevations $\square$ and then $\square$ or so $\square$ e o $\square$ this li $\square$ e $\square$ to the $\square$ orth and Clyde Canal that connected Scotland s west and east coasts $\square$ and (with the $\square$ nion Canal) Glasgow and $\square$ din $\square$ urgh ( $\square$ igure 9). An 1822 advertise $\square$ ent in the Glasgow Courier advised that $\square$ algrochan Li $\square$ e ( $\square$ algrochan $\ulcorner$ eing at the oot o $\square$ the Glenwynd and Langshot li $\square$ e roads $\square \square$ igure 8) was $\sqsubset$ eing sold at Hungryside on the canal $\square$ an $\square$ as well as at the $\square$ algrochan Li $\square$ e Shed at $\square$ ort Dundas $\square$ the Glasgow ter $\square$ inus o $\square$ the canal. ${ }^{39}$ The Glasgow Herald advertised the lease o $\square$ South Craigend $\operatorname{ar} \square$ and its li $\square$ e and coal wor $\square$ in $18 \square 0 \square$ noting that the $\square$ orth and Clyde Canal Whar $\square$ at Hungryside is within three $\square$ iles o the Mines $\square^{40}$ So $\square$ 
li $\square$ e and coal were trans $\square$ orted at least three $\square$ iles $\square$ y cart to the canal. The lin $\square$ $\ulcorner$ etween South Craigend $\operatorname{ar} \square$ and the canal had $\square$ een an enduring one $\square$ ecause the 1836 inventory o $\square$ an intestate South Craigend $\operatorname{ar} \square$ er included: two hundred chalders o $\square \mathrm{li} \square \mathrm{e} \square$ the stoc $\square \mathrm{o} \square$ coals $\square \mathrm{li} \square \mathrm{e} \square \mathrm{c} \mathrm{u} \square$ on the hill or at the wor $\square \mathrm{s} \square$ and a share o $\square$ a $\square$ oat or scow on the canal $\square^{41}$

Other in rastructure associated with li $\square$ ewor $\square$ s included large drains and $\square$ $\square$ resu $\square \mathrm{a} \square \mathrm{y} \square \mathrm{u} \square \square \mathrm{s} \square$ at $\square$ lairs $\square$ aith Trig ( $\square$ igure 6). The looded $\square$ ine entrances in the Trig area con irr $\square$ that there was a water $\square$ ro $\square$ le $\square$ in these $\square$ ines $\square$ des $\square$ ite the wor $\square \mathrm{s}$ $\lceil$ eing on a local high $\square$ oint that was su $\llbracket$ iciently elevated to host a trigono $\square$ etrical survey $\square$ oint. The $\mathrm{u} \square$ hill end o the northern o the two large drains that lead away ro $\square$ the li $\square$ e $\square$ ilns area is adacent to an oval water $\square$ illed de $\square$ ression ( $\square$ igure 6). This de $\square$ ression is inter $\square$ reted as a colla $\square$ sed shat $\lceil$ or $\square u \square \square$ ing water $\square \square$ resu $\square$ a $\square$ y $\square$ y a stea $\square \square$ owered $\square \mathbf{u} \square \square$. The location o the shat and $\square \mathbf{u} \square \square$ or the drain directed to the west $\llbracket$ ro $\square$ the southern edge o $\square$ the Trig $\square$ iln ield is unclear.

$\mathrm{AG} \square \mathrm{O} \square \mathrm{TH} \square \square \mathrm{ALD} \square \mathrm{R} \square \mathrm{OC} \square \square \mathrm{IL} \square \mathrm{S}$

It is li $\square$ ely that the oldest $\square$ aldernoc $\square$ Gilns are the two $\square$ an $\square$ s o $\square$ horseshoe sha $\square$ ed ¿ilns at $\square$ oghall that were not $\square \mathrm{a} \square \square$ ed $\square$ y the OS ( $\square$ igure 3). These $\sqsubset$ ilns now have no surace to $\square$ ogra $\square$ hic e $\square$ ression and were al $\square$ ost certainly well and truly de unct $\square \mathrm{y}$ the ti $\square$ e o $\square \square$ id 19 th century OS $\square \mathrm{a} \square\left[\right.$ ing. ${ }^{42}$ These are a $\square$ ong the s $\square$ allest $\square$ ilns investigated here and they evidently lac $\square$ the so $\square$ histication o $\square$ the su $\square$ surace $\square$ u $\square$ ing seen at South Craigend ( $\square$ igure $\square \square$ ). Moreover $\square$ It is clear ro $\square$ elsewhere that the horseshoe sha $\square$ ed cla $\square \square$ ¿iln is an early $\operatorname{or} \square \square$ nota $\square$ ly ro $\square$ a $\square$ out $20 \square$ to the northeast o $\square \square$ aldernoc $\square$ in $\square \square \square$ er $\square$ annoc $\square$ urn $\square$ where the horseshoe sha $\square$ ed cla $\square \square$ iln is overwhel $\square$ ingly nu $\square$ erically do $\square$ inant and where Harrison has concluded that li $\square$ e $\square$ urning was early ( $\square$ y the late 16th century $\square$ and $\sqsubset$ erha $\square$ s long

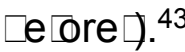

Al $\sqsubset$ eit the horseshoe sha $\square$ ed $\square$ iln is li $\sqsubset$ ely to $\square$ e the early cla $\square \square \square$ iln or $\square \square$ it continued to $\square$ e used and is $\square$ resent in s $\square$ all nu $\square$ ers a $\square$ ong the $\square$ aldernoc $\square$ cla $\square$ cilns $\square$ nota $\square$ ly at South Craigend (two $\square$ ilns) and at the $\square$ lairs $\square$ aith Trig $\sqsubset$ iln ield (two ¿ilns). These horseshoe sha $\square$ ed $\square$ ilns are side $\square \mathrm{y}$ side with the $\square$ ore usual $\square$ sha $\square$ ed Cilns and $\mathrm{a} \square \square$ arently have the sa $\square$ e degree o $\square$ weathering and $\square$ ost $\quad \mathrm{a} \square$ andon $\square$ ent degradation $\square \square$ ointing to their $\square$ eing o $\square \mathrm{a} \square \square$ ro $\square \square$ ately the sa $\square$ e age as the $\square$ sha $\square$ ed 
Cilns. $\square$ otwithstanding the continued use o $\square$ the horseshoe sha $\square$ ed or $\square$ o $\square$ iln $\square$ it is nonetheless concluded here that a concentration o $\square$ the horseshoe sha $\square$ ed or $\square$ indicates an early $\square$ hase $o \square$ the industry.

It is clear that the $\square$ aldernoc $\square \mathrm{li} \square$ e industry o $\square$ erated over a considera $\square$ le ti $\square$ e interval. $\square$ ilns in several localities have $\square$ een $\square$ ac $\square$ illed $\square$ y later activity $\square$ leaving $\square$ iln re $\square$ nants with $\square$ artially in illed $\square$ ac $\square$ ends $\square$ nota $\square$ y the South Craigend grou $\square 7$ ilns ( $\square$ igure $\square$ A) $\square$ where only short re $\square$ nants o $\square$ the ends o $\square$ the horns o $\square$ the seven grou $\square 7$ $\square$ sha $\square$ ed cla $\square \square$ ilns are visi $\square$ le at the oot o $\square$ a slo $\square$ e or $\square$ ing the edge o $\square$ an e $\leftarrow$ tensive and highly $\square$ odilied area that was $\square$ ro $\square$ a $\square$ ly a wor $\square$ area or later $\square$ ining . One cla $\square \square$ illn is also in illed ro $\square$ the $\square$ ac $\square$ at $\square$ orth $\square$ ardowie $\square$ an area not discussed here eyond noting that it was revived in the irst two decades o the 20th century (see Discussion $\square$ elow).

It is assu $\square$ ed that the sedi $\square$ entation and in illing o $\square$ the rectangular $\square \square 1$ dee $\square$ stone lined tan $\square$ at the to $\square$ o $\square$ the South Craigend li $\square$ e road ( $\square$ igure $\square$ ) rellected the decrease in activity in the area and associated lac $\square$ o $\square \square$ aintenance o $\square$ in rastructure as the industry wet into decline. The $\chi^{2}$ statistic or the $\square$ est it or wiggle $\square$ atching the stratigra $\square$ hic se $\square$ uence o $\square$ lead in the in ill sedi $\square$ ents to the dated lead all out record in Loch Lo $\square$ ond yields a $\square$ asal age o $\square$ the in ill sedi $\square$ ents o $\square$ calendar year 1824. $\square$ ( $\square$ igure 10). In act $\square$ the values o $\square$ the $\chi^{2}$ statistic or $\square$ asal ages ranging ro $\square 1819$ to 1843 are all low and $\square$ ro $\square \mathrm{a} \square$ ly all statistically signi iicant (or at least not statistically signi iicantly di $\llbracket$ erent $\operatorname{ro} \square$ each other). The wiggle $\square$ atching $\square$ y the $\square$ acon sotware yields a $\square$ asal age or the South Craigend sedi $\square$ ent in ill o $\square$ calendar year $1828 \square$ with a $9 \square \square$ conidence range o $\square$ calendar years 1831.6 to $182 \square . \square$. The $\square$ atch $\square$ etween the two totally inde $\square$ endent a $\square \square$ roaches to wiggle $\square$ $\square$ atching the South Craigend curve to the dated Loch Lo $\square$ ond curve is $\mathrm{i} \square \square$ ressive.

We ta $\ulcorner$ these data to $\square$ ean that the South Craigend water tan $\square$ started to in ill in the second $\square$ uarter o the 19th century and that the South Craigend li $\square$ e road $\square$ re dated the second $\square$ uarter o $\square$ the $19^{\text {th }}$ century (and $\square$ ro $\square \mathrm{a} \square$ ly long $\square$ re dated that date $\square$ given the scale o $\square$ the li $\square$ ewor $\square$ s at South Craigend). This li $\square$ e $\square$ urning locality was $\square$ nonetheless $\square$ in decline $\square$ y the second $\square$ uarter o $\square$ the $19^{\text {th }}$ century $\square \square$ ut it was not co $\square \square$ letely de unct: the 1841 census o $\square \square$ aldernoc $\square$ records 14 individuals connected with the $\square$ roduction and sale o $\square \mathrm{i} \square \mathrm{e}$ in the $\square$ arish $\square$ including three li $\square \mathrm{e} \square$ asters $\square$ two coal and li $\square$ e $\square$ asters $\square$ ive li $\square$ estone $\square$ iners and one li $\square$ e $\square$ iner two li $\square$ e $\square$ urners 
and one li $\square$ e sales $\square$ an (Ta $\square$ le 2). These were living in South Craigend $\square \square$ arraston and Dru $\square$ loc $\square$ art and the near $\square$ y houses o $\square$ Linn $\square$ an $\square \square$ an $\square$ ier $\square$ Haughhead and Red $\square$ iln ${ }^{44}$ ( $\square$ igure 8). $\square$ aldernoc $\square$ coal $\square$ iners nu $\square$ [ered 12 in $1841 \square$ all residing in Hole $\mathrm{e}\left\lceil\mathrm{ce} \square \mathrm{t}\right.$ one in the neigh $\square$ ouring $\square$ arraston. ${ }^{\square} \square$ The industry was in decline $\square$ however $\square$ $\ulcorner$ ecause $\square \square$ y the $18 \square 1$ census $\square$ the nu $\square \square$ ers involved in li $\square$ e had dro $\square$ ed to si $\square$ all residing in Linn $\square$ an $\square$ Dru $\square$ loc $\square$ art or Haughhead $\square$ and in coal to seven $\square$ living in $\square$ arraston $\square$ Red $\square$ iln or Hole. The 1861 census (Ta $\square$ le 2) reveals that the decline was continuing $\square$ with only one $\square$ erson s e $\square \square$ loy $\square$ ent recorded as li $\square$ e related (a $\mathbb{\text { li }} \square \mathrm{e}$ $\square$ uarrier $\square$ living at Haughead $\square \square$ igure 8). In 1871 $\square$ there were no li $\square$ e wor $\_$ers in $\square$ aldernoc $\square$ and only seven e $\square \square$ loyed in coal.

The industrys ter $\square$ inal decline $\square$ y the $\square$ iddle o $\square$ the 19th century in the area o $\square$ South Craigend is also signalled $\square$ y OS 1st edition $\square \mathbf{a} \square$ ing o $\square$ all o $\square$ that area $\mathbf{s}$ ilns as Old Li $\square$ e $\square$ ilns $\square$ which is ta $\square$ en to $\square$ ean that the $\square$ ilns were no longer unctioning. ${ }^{46}$ This decline in the li $\square$ e industry in $\square$ aldernoc $\square$ is also con ir $\square$ ed $\square$ y advertise $\square$ ents or the lease o $\square$ South Craigend. The $18 \square 0$ Glasgow Herald advertise $\square$ ent noted a $\square$ ove was not the last ti $\square$ e the lease o $\square$ the $\operatorname{ar} \square$ and the associated $\square$ inerals were advertised. They were in act advertised in the Glasgow Herald a rather astonishing $24 \mathrm{ti} \square$ es in $13 \square$ onths in $18 \square 7$ and $18 \square 8$ thus:

Mineral ields in the $\square$ arish o $\square \square$ aldernoc $\square$ Stirlingshire $\square$ or sale. To $\square$ e sold $\square$ y $\square$ rivate $\square$ argain $\square$ irst a lease o $\square$ the coal $\square \mathrm{i} \square$ estone and ironstone in the $\operatorname{ar} \square \mathrm{o} \square$ Hillhead and certain $\square$ arts o $\square$ the $\operatorname{ar} \square \mathrm{s}$ o $\square$ South Craigend and $\square$ an $\square$ eir $\square$ and second a lease o the coal $\square$ li $\square$ estone and ironstone $\square$ and the $\square$ yrites $\square$ alu $\square \square$ schistus $\square \square \mathrm{c}$ in the lands o $\square \square$ arraston. $\square$ oth ields are o $\square$ ened $\mathrm{u} \square \square \mathrm{y} \square$ eans o $\square$ its $\square$ in $\square$ artial o $\square$ eration. ${ }^{47}$

It see $\square \mathrm{s}$ that the leases were not attractive $\square$ with three urther notices in the Glasgow Herald in 1861 advertising the lease o $\square$ South Craigend $\square$ ut this $\mathrm{ti} \square \mathrm{e}$ without $\square$ ention o the coal $\square \mathrm{li} \square$ estone and $\square$ lac $\square \square$ anded ironstone $\square$ erha $\square \mathrm{s}$ signalling the inal de $\square$ ise o $\square$ the $\square$ inerals activity around South Craigend. ${ }^{48}$ In the sa $\square$ e way $\square$ the $\mathrm{e} \square \square$ loy $\square$ ent o the South Craigend inha $\square$ itant in the $18 \square 1$ and 1861 censuses is si $\square \square$ ly that o $\square \square \operatorname{ar} \square$ er $\square$ with no $\square$ ention o $\square$ the Li $\square$ e Master e $\square \square$ loy $\square$ ent o $\square$ two South Craigend inha $\square$ itants in the 1841 census. So $\square$ the li $\square$ e industry in $\square$ aldernoc $\square$ was in decline co $\square$ ing $\mathrm{u} \square$ to the $\square$ iddle o $\square 19$ th century and aded ater 
that. The situation in $\mathrm{Ca} \square \square$ sie has si $\square$ ilarities to and $\square$ arallels with that in $\square$ aldernoc $\square$ $\square$ ut there are $\mathrm{i} \square \square$ ortant di $\llbracket$ erences.

$\mathrm{LIM} \square \square \square \mathrm{R} \square \square \mathrm{GI} \square \mathrm{TH} \square \mathrm{CAM} \square \mathrm{SI} \square \mathrm{AR} \square \mathrm{A}$

$\mathrm{S} \square$ ATIAL DISTRI $\square \square$ TIO

$\square$ igure 2 shows the distri $\square$ ution o $\square$ the li $\square \mathrm{e} \square$ urning areas in the central $\square$ arts o $\square$ Ca $\square \square$ sie $\square$ arish $\square$ Ta $\square$ le 1 indicates the re $\square$ ains o $\square \square$ ore than $3 \square$ ilns $\square$ all o $\square$ the cla $\square$ ciln or $\square \square$ as in $\square$ aldernoc $\square$. As also in $\square$ aldernoc $\square$ there are no draw $\square$ ilns in the $\mathrm{Ca} \square \square$ sie area. The $\square$ rinci $\square$ al areas to $\square$ e discussed here are Culloch Sla $\square \square \square$ aldoran and Sculliongour (also so $\square$ eti $\square$ es con usingly called $\square$ algrochan). The other $\mathrm{Ca} \square \square$ sie area $\square$ near Glorat House ( $\square$ igure 2) $\square$ is not treated in detail here $\square \mathrm{e} \square \mathrm{ce} \square$ to note that the $\square$ id 19th century OS 1st edition $\square \mathrm{a} \square \square$ ed ive cla $\square \square$ iilns that were o $\square$ erating there as the Glorat Li $\square$ e Wor $\square$ s $\square$ ad acent to a Coal and Li $\square$ estone Mine. This wor $\square$ s had closed $\square \mathrm{y}$ the late 19th century 2nd edition $\square \mathrm{a} \square$ ing $\square$ with the $\square$ ilns un $\square \mathrm{a} \square \square$ ed and the $\square$ ine $\llbracket$ eing la $\square$ elled as Old Coal and Li $\square$ estone Mine $\square$ and the na $\square$ e Glorat Li $\square$ e Wor $\square$ s $\square$ now a $\square \square$ lied to the larger li $\square$ e wor $\square$ s near $\square$ y $\square$ here na $\square$ ed $\square$ aldoran (see $\square$ elow).

The 1st and 2nd edition OS $\square \mathrm{a} \square[$ ing con ir $\square$ that the re $\square$ aining $\mathrm{Ca} \square \square$ sie li $\square$ ewor $\square$ s were characterised $\square$ y renewal and regeneration rather than the decline $\mathrm{o} \square$ served in $\square$ aldernoc $\square$ In the $\square$ id 19 th century $1^{\text {st }}$ edition $\square \mathrm{a} \square \square$ ing $\square$ the Sculliongour Li $\square$ e and Coal Wor $\square$ s had our cla $\square \square$ cilns in a line $\sqsubset$ with a ilth $\sqsubset$ ehind those $\square$ all $\mathrm{i} \square \square$ ediately adacent to Mines. The OS 2nd edition shows that $\square \mathrm{y}$ the late 19th century these had $\llbracket$ een re organised and re $\square$ uilt as a $\square$ an $\square$ o $\square$ ive larger cla Cilns in a line $\square$ with three s $\square$ aller cla $\square \square$ Cilns in a $\square$ er $\square$ endicular line at one end o $\square$ the ive $\square$ all served $\square$ y three tra $\square$ ways to the $\square$ id 19 th century $\square$ ine and to $\square$ ore distant $\square$ ines a $\square$ out $200 \square$ ro $\square$ the $\square$ ilns. ${ }^{49}$

The Culloch Sla $\square \mathrm{Li} \square$ e wor $\square$ s ( $\square$ igure 11) and li $\square$ e $\square$ ilns at the adacent $\mathrm{Ca} \square \square$ sie Alu $\square$ Wor $\square$ s are treated here together. Cla $\square \square$ ilns were the sole $\square$ eans o $\square$ $\mathrm{li} \square \mathrm{e} \square$ roduction $\square \mathrm{a} \square \square$ ed in the $\square \mathrm{id} \square$ and late 19th centuries at $\square$ oth Culloch Sla $\square$ and the Alu $\square$ Wor $\square$ s. $\square$ oth sites were o $\square$ viously su $\square$ stantially re organised in the second hal $\square$ o the 19th century $\square$ with Culloch Sla $\square \mathrm{e} \square$ anding its networ $\square$ o $\square \square$ ine tra $\square$ ways $\square$ 
as well as re $\square$ uilding and reducing the nu $\square \square$ er o $\square$ illns (seven to ive $\square$ all cla $\square \square \square$ ilns) $\square$ $\square$ ut also a $\square \square$ arently enlarging the $\square$ ilns ( $\square$ igure 11). The eight Alu $\square$ Wor $\square$ s cla $\square \square$ li $\square \mathrm{e} \sqcap$ ilns were also connected to their $\square$ ines $\square \mathrm{y}$ tra $\square$ ways and to the Ca $\square \square$ sie $\square$ ranch / $\square$ lane Valley $\square$ ranch Railway $\square$ y the $\square$ id 19th century. The 2nd edition OS $\square \mathrm{a} \square \square$ ing indicates that the nu $\square$ er or o $\square$ Alu $\square$ Wor $\square$ s $\square$ ilns re $\square$ ained at eight $\square \square$ ut they were re $\square$ uilt $\square$ su $\square$ stantially re organised and enlarged in the second hal $\square$ o $\square$ the 19th century (Ta $\square$ le 1$)$.

OS $\square \mathrm{a} \square$ ing also con îr $\square \mathrm{s} \square \mathrm{a}$ or re organisation and $\mathrm{e} \square$ ansion o $\square$ the li $\square$ ewor $\square$ s at $\square$ aldoran in the second hal $\square$ o the 19th century ( $\square$ igure 12). Mid 19 th century OS $\square \mathrm{a} \square$ ing shows a s $\square$ all Derry Coal $\square \mathrm{Li} \square \mathrm{e} \mathrm{Wor} \square$ s o $\square$ erating at $\square$ aldoran with two cla $\square \square$ Gilns adacent to a Li $\square$ estone Mine $\square$ A little to the east o $\square$ these wor $\square s$ are $\square \mathrm{a} \square \square$ ed eight $\mathrm{a} \square$ andoned cla $\square \square$ iilns $\square \mathrm{a} \square \square$ ed as Old Li $\square \mathrm{e} \square$ ilns $\square$ ad acent to an Old Li $\square$ estone $\square$ it $\square \square$ y the late 19th century $\square$ the li $\square$ ewor $\square$ s had $\square$ eco $\square$ e the Glorat $\mathrm{Li} \square \mathrm{e}$ Wor $\square \mathrm{s} \square$ and had $\square$ een reorganised and enlarged ( $\square$ igure 12). The two $\square$ id $\square$ 19th century cla $\square \square$ iilns had $\square$ een re $\square$ laced $\square$ y ive larger cla $\square \square$ illns that were serviced $\square$ y tra $\square$ ways $\square$ one leading ro $\square$ the $\square$ ine to a lat $\square$ lat $\square$ or $\square$ a $\square$ ove the $\square$ ac $\square$ s o the cilns ro $\square$ where the $\sqsubset$ ilns were $\square$ resu $\square \mathrm{a} \square$ ly loaded $\square$ and one ro $\square$ the ronts o the ¿ilns downhill to the Ca $\square \square$ sie $\square$ ranch / $\square$ lane Valley $\square$ ranch Railway ( $\square$ igure 12). These $\square$ ilns were now a $\square$ a or industrial o $\square$ eration with a direct connection to the $\square$ ainline railway syste $\square$ that necessitated a $\square$ ridge across the Gla $\sqsubset$ ert Water to oin the railway $\square$ and with one $o \square$ the largest cla $\square \square[$ iln that we have seen in this study $\square$ a $\square$ out $1 \square \square$ long and $\square$ ore than $2 \square$ dee $\square$ ( $\square$ igure 12). It is also $\square$ ossi $\square$ le that the $\mathrm{s} \square$ all $\mathrm{u} \square$ land wor $\square \mathrm{s}$ a $\square$ ove the Glorat Li $\square$ ewor $\square$ s that had $\square$ een $\square \mathrm{a} \square \square$ ed as Old $\square$ (a $\square$ andoned) in the $\square \mathrm{id} 19$ th century saw late stage revival. Here $\square \square \square$ ediately adacent to a shat $\square$ with a second ( $\square$ ossi $\square$ ly air) shat so $\square$ e $7 \square \square$ to the north $\square$ three o $\square$ the eight $\square$ ilns have had their horns shortened. This $\operatorname{ro} \square$ ed out $\square$ aterial has evidently $\square$ een used to renovate one or two $\square$ ilns $\square$ which loo $\square$ resher and less degraded than the other seven $\square$ and $\square$ ay there ore have $\sqsubset$ een used $\square$ ore recently.

$\mathrm{I} \square \mathrm{RASTR} \square \mathrm{CT} \square \mathrm{R} \square \mathrm{A} \square \mathrm{D} \mathrm{AG} \square \mathrm{O} \square \mathrm{TH} \square \mathrm{CAM} \square \mathrm{SI} \square \square \mathrm{IL} \square \mathrm{S}$

It has already $\square$ een noted how the $\mathrm{Ca} \square \square$ sie li $\square$ e $\square$ ilns already had su $\square$ stantial in rastructure associated with the $\square \square \mathrm{y}$ the $\square \mathrm{id} 19$ th century $\square$ including tra $\square$ ways to $\square$ ines and to the railway networ $\square$ It is thus $\square$ ossi $\square$ le ( $\square$ ut $\square$ erha $\square$ s unli $\square$ ely) that the 
$\square$ algrochan Li $\square \mathrm{e} \square$ noted a $\square$ ove as $\sqsubset$ eing advertised or sale in the Glasgow Courier advertise $\square$ ent o $\square 23$ May 1822 ca $\square$ e ro $\square$ the $\square$ algrochan that is near Lenno town (i.e. $\square$ Sculliongour) and had $\square$ een trans $\square$ orted $\square$ y rail to Glasgow $\square$ thence $\square$ y cart to $\square$ ort Dundas and canal to the Hungryside $\square$ ridge. ${ }^{0} \mid \square$ that route is unli $\sqsubset$ ely as an e $\square$ lanation or the li $\square$ e in that $\square$ articular advertise $\square$ ent $\sqsubset$ it is nonetheless clear that $\mathrm{Ca} \square \square$ sie li $\square$ e would have $\square$ een trans $\square$ orted $\square$ y rail.

OS $\square \mathrm{a} \square \square$ ing $\square \mathrm{a}$ es clear that li $\square \mathrm{e} \square$ roduction in the $\mathrm{Ca} \square \square$ sie district e $\square$ anded during the second hal $\square$ o the 19th century. Su $\square$ se $\square$ uent OS $\square$ a $\square \square$ ing shows that the $\square$ aldoran (Glorat) and Culloch Sla $\square \mathrm{li} \square$ e wor $\square$ s had $\square$ eco $\square$ e de unct $\square \mathrm{y}$ the ti $\square$ e o the 1914 revisions o the 6 inch and $2 \square$ inch sheets. These 1914 revisions o $\square$ the 6 inch and $2 \square$ inch $\square \mathrm{a} \square$ s also de $\square$ ict the Ca $\square \square$ sie Alu $\square$ Wor $\square$ s as Disused $\square \square$ ut there is disagree $\square$ ent $\square$ etween the two $\square \mathrm{a} \square$ series on the li $\square \mathrm{e} \sqcap$ ilns at the alu $\square$ wor $\square$ s. The 1914 revision o the 6 inch $\square \mathrm{a} \square \square$ ing $\square \mathrm{a} \square \mathrm{s}$ the li $\square \mathrm{e} \square$ ilns as Li $\square \mathrm{e} \sqcap$ ilns $\square$ without the Disused $\square \mathrm{a} \square \mathrm{el} \square \mathrm{i} \square \square$ lying that they were still o $\square$ erating at that ti $\square \mathrm{e} \square \square$ ut the corres $\square$ onding $2 \square$ inch $\square \mathrm{a} \square$ does not $\square \mathrm{a} \square$ the li $\square \mathrm{e} \square$ ilns at all and la $\square$ els the whole area o $\square$ the alu $\square$ wor $\square$ s including the area where the li $\square \mathrm{e} \square$ ilns were located as Disused $\square$ Ta $\ulcorner$ en as a whole $\square$ the $\square \mathrm{a} \square$ data indicate that li $\square \mathrm{e} \square$ roduction in the $\mathrm{Ca} \square \square$ sie area had $\square$ eco $\square$ e de unct $\square$ y the end o $\square$ the second decade o the 20th century.

The continuing 19th century vigour o $\square \mathrm{i} \square \mathrm{e} \square$ urning in $\mathrm{Ca} \square \square$ sie is re lected in the $\mathrm{Ca} \square \square$ sie $\square$ arish census data (Ta $\square$ le 2) $\square$ with the $\square$ ore than dou $\square$ ling o $\square$ $\mathrm{e} \square \square$ loy $\square$ ent in li $\square \mathrm{e} \square$ etween the 1861 and 1871 censuses $\square$ resu $\square \mathrm{a} \square$ ly re lecting the develo $\square \square$ ents noted a $\square$ ove and in Ta $\square$ le 1. Ta $\square$ le 2 also shows that $\mathrm{e} \square \square$ loy $\square$ ent in coal $\square$ ining in $\mathrm{Ca} \square \square$ sie $\square$ arish li $\square$ ewise increased throughout the second hal $\square \mathrm{o} \square$ the 19th century $\square$ and so $\square$ e o $\square$ that increase is al $\square$ ost certainly related to the li $\square \mathrm{e}$ industry (i.e. $\square$ coal $\square$ iners who were $\square$ ining coal or li $\square$ e $\square$ urning $\square$ ut whose occu $\square$ ations were returned as related to coal).

$\mathrm{DISC} \square S S I O \square$

The Ca $\square \square$ sie li $\square$ e industry lourished in the second hal $\square$ o the 19th century $\square$ y which ti $\square$ e the $\square$ aldernoc $\square$ industry was essentially de unct. S $\square$ all local o $\square$ erations did continue in $\square$ aldernoc $\square$ right $\mathrm{u} \square$ until the early 20th century $\sqsubset$ with a current resident 
recalling his grand ather s leasing and o $\square$ erating o $\square$ the li $\square$ estone $\square$ ine and cla $\square$ $\square$ iln(s) at $\square$ orth $\square$ ardowie in $\square$ aldernoc $\square \square$ arish in the early 1900s. This o $\square$ eration e $\square \square$ loyed two $\square$ en to $\square$ roduce li $\square$ e that was ta $\square$ en $\square$ y horse and cart to $\square$ ardowie railway station ( $\square$ igure 2) or trans $\square$ ort on the or $\square$ er $\square$ orth $\square$ ritish Railway $\square$ elvin Valley Railway line to Glasgow. ${ }^{\square 1}$ To all intents and $\square$ ur $\square$ oses $\square$ however the industry in $\square$ aldernoc $\square$ aded as the $\mathrm{Ca} \square \square$ sie o $\square$ erations grew. The $\mathrm{Ca} \square \square$ sie industry itsel $\square$ then aded.

The $\square$ rie $\square$ early 20 th century revival o the industry in $\square$ aldernoc $\square$ and its reliance on the railway or trans $\square$ ort $\sqsubset$ erha $\sqsubset s \llbracket$ oints to why the industry had earlier aded in $\square$ aldernoc $\square \square$ ut continued in Ca $\square \square$ sie $\square$ na $\square$ ely $\square$ the railway syste $\square$. We have argued a $\square$ ove that the $\mathrm{a} \square$ arent ocus o $\square$ the $\square$ aldernoc $\square$ li $\square$ e roads on the canal whar $\square$ at Hungryside ( $\square$ igure 9) re lects the $\mathrm{i} \square \square$ ortance o $\square$ canal trans $\square$ ort or the li $\square \mathrm{e}$ industry in Scotlands western Central $\square$ elt in the late 18th and early 19th centuries. Thus $\square \mathrm{li} \square \mathrm{e}$ ilns were sited on the canal edge (see $\mathrm{a} \square$ ove $) \square \mathrm{li} \square \mathrm{e}$ was shi $\square \square$ ed and sold at the Hungryside and $\square$ ort Dundas wharves $\square$ and old cla $\square \square \mathrm{li} \square \mathrm{e} \square$ ilns are $\square \mathrm{a} \square \square$ ed on the canal side on OS 1st edition $2 \square$ inch $\square \mathrm{a} \square \mathrm{s}$ at Maryhill on Glasgow $\mathbf{S}$ north ringe and on a short dead end $\mathbf{S} \square$ ur $\square$ o the $\square$ nion Canal near $\square \operatorname{al} \square \operatorname{ir} \square{ }^{2}$ Li $\square$ ewise $\square$ a $\square$ a or canal whar $\square$ to the west o $\square \square$ al $\square$ ir $\square$ in the $\square$ iddle o $\square$ the Central $\square$ elt $\square$ is $\square$ nown as Li $\square$ e Whar $\square$ and connects with a local $\mathrm{Li} \square \mathrm{e}$ Road $\square \square$ ut the railway/s arrival in Scotland S Central $\square$ elt in $1842 \square$ uic $\square$ y drew tra $\square$ ic away ro $\square$ the canal and $\square$ ust have $\square$ ade it di $\square$ icult or the $\square$ a or $\square$ aldernoc $\square$ li $\square$ ewor $\square$ s to co $\square \square$ ete with li $\square$ ewor $\square$ s $\square$ etter situated in relation to e $\square$ erging trans $\square$ ort lin $\square$ s. ${ }^{3}$ Thus $\square$ these li $\square$ ewor $\square$ s were already de unct $\square$ y the ti $\square$ e o $\square$ the $\square$ id 19th century OS $\square \mathrm{a} \square \square$ ing $\square$ e $\sqsubset$ ce $\downarrow$ t or one grou $\square$ o $\square$ cilns at $\square$ lairs $\square$ aith Trig and $\sqsubset$ erha $\square$ s the odd one or two other $\sqsubset$ ilns. The Ca $\square \square$ sie ᄃilns on the other hand $\square$ were clearly o $\square$ erating in the $\square$ id 19 th century and had invested in the in rastructure o $\square$ tra $\square$ way connections to the $\square$ ines and $\square$ in the case o $\square$ the Alu $\square$ Wor $\square$ s li $\square$ e $\square$ ilns to the $\square$ ainline railway syste $\square$. Ca $\square \square$ sie $\mathrm{S} \square$ a or grou $\square \mathrm{s}$ o $\square$ ¿ilns then re organised and $\mathrm{e} \square$ anded in the second hal $\square$ o the 19th century $\square$ installing larger $\square$ ilns and $\square$ aintaining $\square$ Alu $\square$ Wor $\square$ s Li $\square$ ewor $\square$ s $\square$ or develo $\square$ ing $\square$ Glorat Li $\square$ ewor $\square$ S connections to the railway syste $\square$. The $\square$ id 19 th century Glorat House li $\square$ ewor $\square$ s was closed $\square$ y the late 19th century $\square \square$ ut the Sculliongour wor $\square \square$ $\square$ ore distant $\llbracket$ ro $\square$ the railway was re organised in the second hal $\square$ o the 19 th century. $\square$ resu $\square \mathrm{a} \square$ ly its li $\square$ e was carried to the near $\square$ y railway $\square$ y horse and cart. 
I $\square$ the s $\square$ all horseshoe sha $\square$ ed $\square$ iln $\square$ which is the only $\sqsubset$ iln ty $\square$ e $\square$ resent at $\square$ oghall and is occasionally seen elsewhere in $\square$ aldernoc $\square$ re $\square$ resents the early stages in the evolution o $\square$ cla $\square \square \square$ ilns $\square$ as the co $\square \square$ ents o $\square$ Harrison and Mac $\square$ ay indicate $\square$ with the technology then evolving into the $\square$ sha $\sqsubset$ ed $\square$ ilns that cul $\square$ inate in large industrial $\square$ scale cla $\square \square$ cilns $\square$ ore than $1 \square \square$ long then li $\square \mathrm{e} \square$ urning technology $\square$ ased on cla cilns in Scotlands western Central $\square$ elt evolved over the lie o $\square$ the industry in the $\square$ aldernoc $\square \mathrm{Ca} \square \square$ sie area. ${ }^{\square 4}$ An inter $\square$ retation that the earlier $\square$ hases o $\square$ the industry were in $\square$ aldernoc $\square$ is su $\square \square$ orted $\square$ y $\square$ oghalls $\square$ an $\square$ o $\square 17$ horsehoe sha $\square$ ed cla $\square \square$ ¿ilns. S $\square$ all horseshoe sha $\square$ ed $\square$ ilns continued to $\square$ e used locally in $\square$ aldernoc $\square$ at $\square$ oth the South Craigend and $\square$ lairs $\square$ aith Trig $\sqsubset$ iln ields $\square$ and only one $\square$ ossi $\square$ ly horseshoe sha $\square$ ed cla $\square \square$ Cilns has $\square$ een identilied in Ca $\square \square$ sie (at the Old Li $\square$ e $\square$ ilns to the east o $\square \square$ aldorans Glorat Li $\square$ e Wor $\square$ s $\square \square$ igure 12). In other words $\square$ it can $\square$ e argued that the $\square$ aldernoc $\square$ industry develo $\square$ ed earlier than that in $\mathrm{Ca} \square \square$ sie $\square$ though caution is needed with that inter $\square$ retation $\lceil$ ecause the wides $\square$ read redevelo $\square \square$ ent o $\square$ the $\mathrm{Ca} \square \square$ sie industry could have o $\square$ literated re $\square$ ains o $\square$ any horseshoe sha $\square$ ed cla $\square \square$ ¿ilns.

Whatever a $\square$ out that $\square$ oint o $\square$ detail $\square$ the unda $\square$ ental $\square$ oint to $\square$ e $\square$ ade here is that cla $\square \square \square$ ilns re $\square$ ained the sole technology or li $\square$ e $\square$ urning in the study area $\square$ not one draw $\square$ iln has $\square$ een identilied in an area that has evidence o $\square \square$ ore than $1 \square 0$ cla $\square \square$ cilns. Thus there is no evidence that tenant $\square$ ohn Lochrys underta $i$ ing in a letter o $\square$ uly 291813 to $\square$ ohn $\square$ incaid $\square$ the owner o $\square$ the Woodhead $\square$ state that covers the study area $\square \square$ ind ing Lochry $\square$... to $\square$ uild a draw $\sqsubset$ iln or $\square$ urning li $\square$ e in the course o $\square$ the ne $t$ year $\sqsubset$ was ever ulilled.

The e $\square$ clusive ocus on cla $\square \square$ Ciln technology in a $\square$ a or li $\square$ e $\square$ roducing area highlights the ina $\square \square$ ro $\square$ riateness o $\square$ the wides $\square$ read and al $\square$ ost $\mathrm{e} \llbracket$ clusive $\mathrm{e} \square \square$ hasis on draw $\sqsubset$ ilns as e $\square \square$ le $\square$ atic o $\square$ the historical li $\square$ e industry in Scotland. $\square$ ohnsons re $\square \operatorname{ar} \square$ in relation to Yor $\square$ shire $\square$ It is regretta $\square$ le that there is no $\square$ recognition o $\square$ the role o $\square$ cla $\square \square$ cilns in the develo $\square \square$ ent o $\square$ li $\square$ e $\square$ urning technology $\square$ evidently a $\square \square$ lies $\mathrm{e} \square$ ually to Scotland. ${ }^{6} \mathrm{Re} \square \mathrm{e} \square \square$ ering that in this area the relevant $\square$ art o $\square$ the geological se $\square$ uence consists o $\square \mathrm{li} \square$ estone inter $\square$ edded with coal $\square$ it is reasona $\square$ le to conclude that the do $\square$ inance o $\square$ cla $\square \square \square$ ilns in the $\square$ aldernoc $\square \mathrm{Ca} \square \square$ sie area $\square$ artly re flects the relative ease $\mathrm{o} \square \mathrm{o}$ taining the li $\square$ estone and coal with which to charge the 
Cilns. This inter $\square$ retation is consistent with the siting o $\square$ ilns $\mathrm{i} \square \square$ ediately adacent to $\square$ ine entrances ro $\square$ where the coal and li $\square$ estone could $\square$ e loaded directly into cilns. $\square$ ut it $\square$ ust also $\square$ e re $\square \mathrm{e} \square \square$ ered that li $\square \mathrm{e} \square$ urners o ten $\square$ re erred cla $\square \square \square$ ilns. Thus $\square$ Car $\square$ ichael noted in the 1830s:

These cla $\square \square \square$ ilns are $\square$ re erred $\square \mathrm{y} \square$ any to the draw ilns $\square$ on account o $\square$ the slow and su $\square$ erior $\square$ anner in which the stones are calcined $\square$ whereas the $\square$ ractice o $\square$ daily re $\square$ oving a $\square$ uantity o $\square$ li $\square$ e ro $\square$ the draw ¿iln $\square$ either hurries the o $\square$ eration or de eats it $\square \square$ ringing down the li $\square$ estone $\square$ e ore it is thoroughly calcined. $\square$

The installation o $\square$ large cla $\square \square$ illns at the Glorat Li $\square$ e Wor $\square$ s at $\square$ aldoran (Ca $\square \square$ sie) in the second hal $\square$ o the 19th century is telling in this regard $\square$ in that the o $\square$ erators $0 \square$ a $\square$ a or industrial scale li $\square$ e $\square$ urning venture $\sqsubset$ connected $\square$ y a tra $\square$ way to the $\square$ ainline railway syste $\square$ installed large (1 $\square \square$ long) cla $\square \square$ iilns. OS 2nd edition $2 \square$ inch $\square \mathrm{a} \square \square$ ing o $\square$ the $\square$ al $\mathbf{a} \square$ ray area near Milngavie shows that si $\square$ large cla $\square \square \square$ ilns $\mathrm{u} \square$ to $16 \square$ long were also installed there $\square \mathrm{a} \square$ out $7 \square$ west $\$$ south west o $\square$ the $\square$ aldernoc $\square$ study area $\square$ in the second hal $\square$ o the 19th century $\square$ again $\square$ draw $\square$ ilns were not used. ${ }^{8}$ This enter $\square$ rise $\square$ la $\square$ elled $\square$ al $\mathbf{a} \square$ ray Wor $\square$ (Coal $\square \mathrm{Li} \square \mathrm{e}$ ) $\sqsubset$ on OS 2nd edition $\square \mathrm{a} \square \square$ ing $\square$ was not close to a rail line $\square$ ut the road connections to Glasgow see $\square$ to have $\sqsubset$ een reasona $\square$ le.

The $\square$ re erence or cla $\square \square$ iilns is also evident in other $\square$ arts o $\square$ central and western Scotland. It has already $\square$ een noted that the $4 \square$ horseshoe sha $\sqsubset$ ed cla $\square$ cilns in u $\square \square$ er $\square$ annoc $\square \square$ urn (Stirlingshire) are li $\lceil$ ely to $\square$ e early. Around $\square$ raehead in Lanar $\square$ shire $\square$ to the southeast o $\square$ the $\square$ resent study area $\square$ Ward has geo re rerenced $\square$ ore than 140 cla $\square \square \square$ ilns. ${ }^{9}$ Si $\square$ ilarly $\square \square$ is $\square$ et docu $\square$ ents $\square$ any tens o $\square$ cla $\square \square \square$ ilns in Ren rewshire in western Scotland $\square$ noting that they were used $\square$ as in $\square$ aldernoc $\square$ and $\mathrm{Ca} \square \square$ sie $\square$ throughout the li e o $\square$ the li $\square \mathrm{e} \square$ urning industry in highly organised $\square$ industrial scale o $\square$ erations ${ }^{60}$. $\square$ is $\square$ et also co $\square \square$ ents that cla $\square \square$ iilns were oten used side $\square$ y side with draw $\square$ ilns $\square \square$ ut notes various reasons or $\square$ re erring the cla $\square \square \square i l n \square$ to which can $\square$ e added the reason noted here $\square$ na $\square$ ely $\square$ their ease and si $\square \square$ licity o $\square$ o $\square$ eration when $\square$ oth li $\square$ estone and coal occurred together in the geological se $\square$ uence. $\square$ is $\square$ et noted that so $\square$ e o $\square$ the large cla $\square \square \square$ ilns in Ren rewshire were $\square$ ore than $20 \square$ in length (i.e. $\square$ larger than the largest cla $\square \square$ ciln identilied in this study) and $\mathrm{i} \square \square$ lied that cla $\square \square$ cilns were oten $\square$ re erred even when the coal had to $\square$ e $\square$ rought to the li $\square$ estone. And inally on this $\square$ oint o $\square$ the $\mathrm{u} \square \square$ uity o $\square$ cla $\square \square \square$ ilns in 
western Scotland $\square$ a geograph we $\llbracket$ site $\square$ Relics o $\square$ the li $\square$ estone industry on Du $\square \square$ arton Muir $\square$ docu $\square$ ents $\square$ any old li $\square$ e related eatures on Du $\square \square$ arton Muir $\square$ including li $\square$ estone $\square$ uarries $\square$ trac $\square$ s related to the $\mathrm{li} \square$ e industry and cla $\square \square \square$ ilns. ${ }^{61}$ Incidentally $\square$ later draw $\square$ ilns are also docu $\square$ ented or this Du $\square \square$ arton site.

It is also clear ro $\square$ the historical literature $\square$ as well as the ro $\square$ re $\square$ ains o $\square$ draw $\square$ ilns the $\square$ selves $\square$ that there was no universally acce $\square$ ted design or draw $\square$ ilns $\square$ which were su $\square$ ect to considera $\square$ le stresses when ully loaded and $\square$ eing ired. ${ }^{62}$ Co $\square \square$ on solutions to this issue included the $\square$ ost construction $\square$ uttressing o the $\square$ asonry $\square$ ilns and/or enclosing o $\square$ the $\square$ ot o $\square$ the draw $\square$ iln within a $\square$ assive (and $\square$ resu $\square \mathrm{a} \square$ ly e $\square$ ensive) $\square$ asonry structure $\square \square$ the outset ( $\square$ igure 13). ${ }^{63}$ Such solutions were $\square$ resu $\square \mathrm{a} \square$ y dee $\square$ ed necessary to usti y the cost o $\square$ ringing in the raw $\square$ aterial when coal or li $\square$ estone had to $\square$ e $\square$ rought to the li $\square$ ewor $\square$ s and iring o $\square$ the $\square$ iln was (se $\square \mathrm{i} \square$ )continuous. At the Charlestown whar $\square$ side li $\square$ ewor $\square$ s $\square$ or e $\square$ a $\square \square$ le $\square$ coal was $\square$ rought in $\square$ y rail ro $\square$ Dun er $\square$ line and the li $\square$ estone $\square$ uarried on site. $^{64} \square$ resu $\square \mathrm{a} \square$ ly the cost o $\square$ trans $\square$ orting coal was o $\square$ set $\square \mathrm{y} \square$ eing a $\square$ le to ire the draw $\sqsubset$ ilns continuously and then to load the li $\square$ e directly into shi $\square$ s or trans $\square$ ort to $\square$ ar $\lceil$ ets throughout eastern Scotland $\square$ as well as $\square$ y the returns ro $\square$ shi $\square$ ing and selling coal itsel $\sigma^{6}$ When either coal or li $\square$ estone had to $\square \mathrm{e} \square$ rought to the $\square$ iln $\square$ it generally $\square$ ade sense to locate the ilns at the source o $\square$ li $\square$ estone $\square$ ecause o $\square$ the $\square 0 \square$ weight loss in calcining li $\square$ estone to li $\square$ e and the generally higher $\square$ ro $\square$ ortion o $\square$ li $\square$ estone to coal in the $\square$ iln charge (see a $\square$ ove).

Thus $\square$ and notwithstanding $\square$ any li $\square \mathrm{e} \square$ urners $\square$ re erence or draw $\square$ ilns and these $\square$ ilns $\square$ undou $\square$ ted wides $\square$ read use in Scotland $\square$ it re $\square$ ains clear ro $\square \mathrm{Ca} \square \square$ sie $S$ Glorat Li $\square$ ewor $\square$ s and Culloch Sla $\square \mathrm{Li} \square$ ewor $\square$ s and the $\square$ ala $\square$ ray Wor $\square$ s $\square$ as well as ro $\square \square$ is $\square$ et $\mathrm{S}$ wor $\square$ in Ren rewshire $\square$ that cla $\square \square$ illns were a $\square$ er ectly via $\square$ le and econo $\square$ ic technology or industrial scale $\square$ roduction o $\square$ li $\square$ e until at least the end o $\square$ the 19th century. The re $\square$ uilding o $\square \square$ oth o $\square$ the Glorat and Cullch Sla $\square$ Li $\square$ ewor $\square$ s in the second hal $\square$ o $\square$ the 19 th century $\square$ the considera $\square$ le si $\square$ e o $\square$ these wor $\square$ s $\square$ largest cla $\square \square$ cilns $\square$ and the $\mathrm{li} \square$ ewor $\square$ s connections $\square \mathrm{y}$ tra $\square$ ways $\square$ oth to $\square$ ines and to the $\square$ ain rail networ $\square$ or shi $\square$ ing o $\square$ the li $\square \mathrm{e} \square$ all con ir $\square$ the scale o the li $\square$ ewor $\square \mathrm{s} \square$ in rastructure and econo $\square$ ic invest $\square$ ent.

The cla $\square \square$ ciln was a low cost and relatively straight $\square$ orward way to $\square$ urn li $\square$ estone $\square$ ut the $\square$ ethod nonetheless needed care and attention. As we have noted $\square$ the li $\square \mathrm{e} \square$ urner aced two contrary challenges: cla $\square$ ing the $\square$ iln was necessary in 
order to control the rate o $\square$ urning and hence the te $\square \square$ erature $\square$ too hot and the $\mathrm{li} \square$ estone would have $\square$ een calcined to useless $\square$ over $\square$ ired clin $\lceil$ er stone $\square \square$ ut calcining li $\square$ estone $\square$ roduces car $\square$ on dio ide which e $\square$ tinguishes la $\square \mathrm{e}$ i $\square$ it is not vented and/or $\mathrm{i} \square \mathrm{o} \square$ ygen is not su $\square$ lied to the $\square$ urning charge. Historical accounts $\mathrm{o} \square$ $\mathrm{li} \square \mathrm{e} \square$ urning in cla $\square \square \square$ ilns in $\square$ aldoran noted the need to su $\square \square$ ly air to the $\square$ urning charge $\square$ this challenge $\square$ eing $\square$ et at $\square$ aldoran $\square$ y the $\square$ iln carry ing three s $\square$ all $\square$ ies or $\square$ ens through the $\square$ otto $\square \square$ and $u \square$ the sides and ends o $\square$ the $\square$ iln $\square$ in order to give the $\square$ air. $66 \square$ urther gradio $\square$ eter survey and $\mathrm{e} \square$ cavation o $\square$ the $\square$ aldernoc $\square$ cla $\square$ cilns re $\square$ orted here will con $\operatorname{ir} \square \mathrm{i} \square$ the su $\square$ sur ace eatures tentatively identilied in the South Craigend gradio $\square$ eter survey are indeed $\square \mathrm{lu} \square$ ing to control the air su $\square \square \mathrm{ly}$.

$\mathrm{STR} \square \mathrm{CT} \square \mathrm{R} \square \mathrm{O} \square \mathrm{I} \square \mathrm{D} \square \mathrm{STRY}$

The Glorat Li $\square$ ewor $\square$ de $\square$ onstrate that the industry was highly organised $\square$ y the late 19th century $\square$ ut it is e $\square$ ually clear that that degree o $\square$ organisation had $\mathrm{e}$ isted or a considera $\square$ le ti $\square$ e as $\square$ a or clusters o $\square$ ilns around $\square$ ine o $\square$ enings are co $\square \square$ on throughout the $\square$ aldernoc $\square \mathrm{Ca} \square \square$ sie area $\square$ including at South Craigend $\square \square$ lairs $\square$ aith Trig $\square \square$ aldoran $\square$ Culloch Sla $\square \square \square$ oghall $\square$ and so on. $\square \square$ ually $\square$ there were s $\square$ all scale $\square$ indeed $\square$ erha $\square$ s lone $\square$ o $\square$ erators $\square$ such as at South Craigend $\square \square$ ut even these s $\square$ all $\square$ scale o $\square$ erators generally located their $\square$ iln close to a $\square$ ine.

The news $\square \mathrm{a} \square$ er advertise $\square$ ents noted $\mathrm{a} \square$ ove indicate that the $\mathrm{li} \square$ ewor $\square \mathrm{s}$ $\mathrm{o} \square$ eration was $\square$ y landowners and estates leasing out the $\square$ ineral rights. Leases co $\square \square$ only included incentives $r$ ro $\square$ the landowner $\square$ such as those in an 1813 lease $\square$ etween $\square$ ohn $\square$ incaid o $\square \square$ incaid (the landowner) and $\square$ ohn Lochry (Loughry) in which $\square$ incaid agreed to $\square$ ay $\square 100$ towards the sin $\square$ ing o $\square$ a $\square$ it to the coal $\square \square 30$ when the $\square$ it had reached $1 \square$ atho $\square \mathrm{s} \square[30$ on reaching the coal $\square$ and the re $\square$ aining $\square 40$ when the a $\square$ ove ground wor $\square$ s leading to the wor $\square$ s were inished. ${ }^{67}$ The lease also o $\square$ liged the landowner to $\square$ rovide the gin (winding gear) $\square$ gin ro $\square$ es and hutches $\square$ windlass wheel and ro $\square$ es and other $\square$ aterial used or $\square$ oving $\square$ aterials and $\square$ en $\mathrm{u} \square$ and down the $\square$ it shatt. And thirdly $\square$ rent was $\square 100$ or the irst year ( $\square$ resu $\square \mathbf{a} \square$ ly as an incentive when there was no $\square$ roduction) $\square$ ut then rose to $\square 160$ years or the re $\square$ aining nine years o the lease $\square$ lus Lordshi $\square$ s o $\square$ one ninth o $\square$ the gross out $\square$ ut o $\square$ coal $\square$ one seventh $\square$ art o $\square$ the sale o $\square \mathrm{li} \square$ e and one shilling $\square$ er ton o $\square$ the sale o $\square$ green $\square$ (un $\square$ urnt) li $\square$ estone. 
$\mathrm{CO} \square \mathrm{CL} \square \mathrm{SIO} \square \mathrm{S}$

ohnson has co $\square \square$ ented that li $\square$ e is the Cinderella o $\square$ industrial archaeology. ${ }^{68}$ The results $\square$ resented here $\square$ ean that that can $\square \mathrm{e}$ e tended to say that cla $\square \square[$ ilns are the Cinderella o $\square \mathrm{li} \square \mathrm{e} \quad \square$ iln archaeology $\square$ rarely investigated and even $\square$ ore rarely e $\sqsubset$ cavated. The a $\square$ undance o $\square$ cla $\square \square$ ciln re $\square$ ains in the $\square$ aldernoc $\square \mathrm{Ca} \square \square$ sie area $\square$ rovides the o $\square \square$ ortunity to $\mathrm{e} \square$ lore the details o $\square$ this technology $\square$ there $\square \mathrm{y}$ to $\mathrm{e}$ tend ohnsons intriguing results on cla $\square \square \square$ iln structure and unction. ${ }^{69}$ The e clusive use o $\square$ cla $\square \square$ ilns in the $\square$ aldernoc $\square \mathrm{Ca} \square \square$ sie area is reasona $\square$ ly e $\square$ lained $\square$ y a co $\square \square$ ination o $\square$ a regional $\square$ re erence or cla $\square \square \square$ ilns (i.e. $\square$ local custo $\square$ and $\square$ ractice) and the $\square$ ossi $\square$ ility o $\square$ e tracting inter $\square$ edded coal and li $\square$ estone in the one $\square$ ine or uarry. That hy $\square$ othesis $\square$ ust await urther archival wor $\square \square$ ut even $\mathrm{i} \square \square$ oth actors are con ir $\square$ ed $\square$ it re $\square$ ains clear $\square$ ro $\square$ the historical literature on li $\square$ e $\square$ urning and $r$ ro $\square$ $\square$ is $\square$ et S data ro $\square$ Ren rewshire $\square$ that so $\square$ e li $\square$ e $\square$ urners si $\square \square$ ly $\square$ re erred cla $\square$ ¿ilns $\square$ and that cla $\square \square$ and draw $\square$ ilns o $\square$ erated side $\square$ y side at the $\square$ ea $\square \mathrm{o} \square \mathrm{i} \square \mathrm{e} \square$ $\square$ urning in Scotlands western Central $\square$ elt. In other words the cla $\square \square$ ¿iln was itsel $\square$ a so $\square$ histicated technology that was not si $\square \square$ ly a $\square$ recursor to $\square$ ore so $\square$ histicated draw cilns. The s $\square$ ill re $\square$ uired to o $\square$ erate a cla $\square \square[$ iln $\square \square$ oth in ter $\square$ s o $\square$ loading it and then controlling the $\square$ urn $\square$ could $\square$ e rewarded $\square$ y a higher $\square$ uality li $\square$ e $\square$ as Car $\square$ ichael $\left\lceil\right.$ ointed out. ${ }^{70}$ In short $\square$ cla $\square \square$ Cilns were not necessarily used si $\square \square$ ly as a local $\square$ S $\square$ all scale technology that $\square$ ight have $\square$ een ired only once to $\square$ roduce li $\square$ e or agriculture $\square \square$ ut were a central ele $\square$ ent in a highly organised industry su $\square \square$ lying a $\square$ ey ingredient in the develo $\square \square$ ent o $\square$ Scotlands industry $\square$ econo $\square$ y and ur $\square$ an centres.

$\mathrm{AC} \square \square \mathrm{OWL} \square \mathrm{DG} \square \mathrm{M} \square \square \mathrm{TS}$

We than $\square$ landowners in $\square$ aldernoc $\square$ and $\mathrm{Ca} \square \square$ sie or access to $\square$ ilns on their $\square$ ro $\square$ erties $\square$ es $\square$ ecially Willia $\square$ and Alec Henderson o $\square \square$ ettlehill and David Ralston o $\square$ Castlehill $\square$ or $\square$ er $\square$ ission to underta $\square$ e the geo $\square$ hysical surveys at $\square$ oghall and South Craigend $\square$ res $\square$ ectively $\square$ and the Stirlings o $\square$ Glorat or access to the $\sqsubset$ iln re $\square$ ains at $\square$ aldoran. We also than $\square$ sta $\square$ at $\square$ ast Dun $\square$ artonshire s Willia $\square \square$ atric $\square$ Li $\square$ rary $\square \square$ ir $\square$ intilloch $\square$ or assistance with census data $\square$ and the $\square$ ational Li $\square$ rary o $\square$ Scotland or $\square$ er $\square$ ission to use the e $\square$ tracts ro $\square$ Ordnance Survey $\square \mathrm{a} \square$ s. The 
$\square$ niversity o $\square$ Glasgows School o $\square$ Geogra $\square$ hical $\square \square$ arth Sciences $\square$ indly $\square$ et the $\square$ ational Li $\square$ rary o $\square$ Scotlands ee or $\square$ er $\square$ ission to $\square$ u $\square$ lish these e tracts. $\square$ enny Ro $\square$ erts $\square$ ield Technician in the $\square$ niversity o $\square$ Glasgow S School o $\square$ Geogra $\square$ hical $\square$ arth Sciences $\square$ rovided $\square$ as always $\square$ cheer $\square$ ul and energetic ield assistance $\square$ and $\square$ icola $\square$ rannan $\square$ S $\square$ all Ani $\square$ al Diagnostic I $\square$ ager at the $\square$ niversity o $\square$ Glasgow School o $\square$ Veterinary Medicine $\square$ indly $\square$ roduced the $\square$ rays o $\square$ the South Craigend sedi $\square$ ent cores. Mi $\sqsubset$ e Hels $\square$ y o $\square$ Low $\square$ lochairn $\square$ generously assisted with the coring o $\square$ this sedi $\square$ ent and undertoo $\square$ the care $u$ ul sedi $\square$ entological analyses that under $\square$ in our inter $\square$ retation o the core. Valerie Olive o $\square$ the Scottish $\square$ niversities $\square$ nviron $\square$ ental Research Centre analysed the South Craigend core sa $\square \square$ les or content $\square$ or co $\square \square$ arison with the dated total lead $\square$ roile ro $\square$ Loch Lo $\square$ ond indly $\square$ rovided $\square$ y Dr $\square$ ohn $\square$ ar $\square$ er o $\square$ the $\square$ niversity o $\square \square$ din $\square$ urgh. $\square$ ro essor Marian Scott $\square$ $\square$ niversity o $\square$ Glasgow School o $\square$ Mathe $\square$ atics and Statistics $\square$ gave thought ul advice on wiggle $\square$ atching $\square$ and Dr Maarten $\square$ laauw $\square \square$ ueens $\square$ niversity $\square$ el ast $\square$ was generous with his ti $\square$ e in underta $\square$ ing the wiggle $\square$ atching using his $\square$ acon $\square$ so tware $\square$ and in $\mathrm{e} \square$ laining the results. We are grate $u$ l to all o $\square$ these individuals or their essential assistance and advice. 
$\square \mathrm{OT} \square \mathrm{S} \mathrm{A} \square \mathrm{D} \mathrm{R} \square \square \square \mathrm{R} \square \square \mathrm{C} \square \mathrm{S}$

1 ohnson $\square$. Limestone Industries of the Yorkshire Dales (Stroud: Te $\square \square$ us $\square$ 2nd edition $\square$ 2010) $\square$

Willia $\square \mathbf{s} \square$ R. Lime Kilns and Lime Burning (Ayles $\square$ ury: Shire $\square$ oo $\square \mathbf{s} \square 1989$ ).

$2 \square$ o $\square$ ey $\square$. $\square$ A $\square$ ote on Sow $\square \square$ ilns $\square$ J ournal of the Newcastle upon Tyne Agricultural Society $\square 20$

(1966) $\square 37 \square 8 \square \square$ is $\square$ et $\square$ S. $\square$ The 18th Century Li $\square$ e Industry in Scotland $\square$ S cottish Local History $\square 8$

(2003) $\square \square 13$.

${ }^{3}$ Mitchell $\square$. and $\square$. $\square$ isho $\square \square \mathrm{Li} \square \mathrm{e} \square$ ilns $\square$ still a $\square$ urning issue $\square$ Sheetlines (The J ournal of the Charles

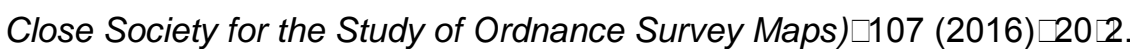

${ }^{4}$ Car $\square$ ichael $\square \square \square$ Account o the $\square$ rinci $\square$ al li $\square$ estone $\square$ uarries o $\square$ Scotland $\square$ Transactions of the Highland and Agricultural Society of Scotland (New Series) $\square \square$ (1837) $\square \square 784 \square \square$ or $\square$ eat: Ga $\square$ ney $\square$ V. The Lordship of Strathavon: Tomintoul under the Gordons (A $\sqsubset$ erdeen: The Third $\mathrm{S} \square$ alding Clu $\square \square$ 1960) $\square 43 \square$ Willia $\square \mathrm{s} \square \square \square$ Suggestions or $\square$ ro $\square$ oting $\square \mathrm{i} \square \square$ roving the isheries $\mathrm{u} \square$ on the coasts o $\square$ Highlands and Isles $\square$ P rize Essays and Transactions of the Highland and Agricultural Society of Scotland $\square 1$ (1799) $\square 2 \square 0 \square 4$.

Car $\square$ ichael $\square$ re $\square 4$.

6 Ibid. $\square$ ohnson $\square$ D. $\square$ The archaeology and technology o $\square$ early $\square$ odern li $\square \mathrm{e} \square$ urning in the Yor $\square$ shire Dales: Develo $₫$ ing a cla $\square \square[i$ iln $\square$ odel $\square$ Industrial Archaeology Review $\square 30$ (2002) $\square 127 \llbracket 43$.

$7 \square$ is $\square$ et $\square$ S. $\square$ The Archaeology o $\square$ the Li $\square$ e Industry in Ren rewshire $\square$ Renfrewshire Local History Forum J ournal $\square 13(200 \square) \square 41 \square 8$

${ }^{8} \mathrm{~S} \square$ out $\square$ T.C. and A. $\square$ enton $\square$ Scottish agriculture $\square$ e ore the I $\square \square$ rovers $\square$ an e $\square$ loration $\square$ The Agricultural History R eview $\square 13$ (196 $\square) \square 2$.

9 Li $\square$ ing was the single $\square$ ost $\mathrm{i} \square \square$ ortant ste $\square$ in agricultural $\mathrm{i} \square \square$ rove $\square$ ent in 18th century Scotland Hay $\square$. $\square$ Cro $\square$ s and livestoc $\square$ in the I $\square \square$ rove $\square$ ent $\square$ ra $\square$ in $\square$ enton $\square$ A. $\square \square$. Veitch $\square($ eds.) $\square$ Scottish Life and Society, a Compendium of S cottish Ethnology. Volume 2. Farming and the Land ( $\square$ din $\square$ urgh: ohn Donald 2011) 248.

10 The a $\square$ lication o $\square$ calcareous $\square$ arl (a $\square$ uddy clay rich in li $\square$ e) could achieve the sa $\square$ e e $\square$ ect $\square$ ut re $\square$ uired very su $\square$ stantially greater $\square$ uantities o $\square \square$ arl (4 $\square 0600$ cartloads $\square$ er acre $) \square$ co $\square \square$ ared to li $\square$ e (1080 carts $\square$ er acre) $\square$ Dodgshon $\square$ R. $\square$ Land $\mathrm{i} \square \square$ rove $\square$ ent in Scottish ar $\square$ ing: Marl and li $\square$ e in Ro $\square$ urghshire and $\square$ erwic $\square$ shire in the eighteenth century $\square$ The Agricultural History Review $\square 24$ (1978) $\square 1414$.

$11 \square$ enton $\square$ A. $\square$ S cottish Country Life ( $\square$ din $\square$ urgh: $\sqsubset$ ohn Donald $\square 1976$ ) $\square$ White $\square$. $\square$ Agriculture and Society in Seventeenth-Century Scotland ( $\square$ din $\square$ urgh: $\square$ ohn Donald $\square$ 1979) $\square$ Harrison $\square \square \square \mathrm{Li} \square$ e su $\square \square$ ly in the Stirling area $r o \square$ the 14 th to the 18th centuries $\square$ Forth Naturalist and Historian 16 (1993) $\square 39 \square$ Hay $\square$ re $\square 9 \triangleleft \mathrm{S} \square$ out and $\square$ enton $\square$ re $\square 8 \square 73 \square \square$ or e $\square \square \square$ le $\square$ a eu contract o $\square 1630 \square$ etween the $\square$ arl o $\square$ Montrose and three $\square$ ersons in $\square$ aster $\square$ algrochan (Stirlingshire) gives the $\square$ the $\square$ rivilege o $\square$ winning coal and li $\square$ e through the ive and a hal $\square \square$ er $\square$ land o $\square$ Carlestoun and $\square$ aster and Wester $\square$ algrochan as o $\square$ old $\square(\square$ AS GD220/6/330/1 $\square \mathrm{L} \square 01 / 49 \square \square \square 1630 \square \square$. $\square$ ). The $\square$ algrochan re erred to here is in the central $\square$ art o $\square$ the $\square$ aldernoc $\square \mathrm{Ca} \square \square$ sie study area. 
$12 \square$ elsches $\square$ R. $\square$ General View of the Agriculture of the County of Stirling With Observations on the Means of its Improvement ( $\square$ din $\square$ urgh: $\square$ oard o $\square$ Agriculture and Internal I $\square \square$ rove $\square$ ent $\square 1796$ ). $13 \square$ ow $\square$ an $\square$. History $\square$ in Carter $\square \square$. (ed.) $\square$ The Forth \& C lyde Canal Guidebook ( $\square$ ir $\square$ intilloch: $\square$ orth Clyde Canal Society 3 rd edition $\longleftarrow 2001) \square 44$.

$14 \square \square$ lanation o $\square$ Mr $\square$ arrys $\square$ lan o $\square$ Survey o $\square$ Craig $\square$ addie Muir $177 \square \square \square$ niversity o $\square$ Glasgow Archives $\square$ GD $1 \llbracket 2 / 6 \square$ undle 2

$1 \square$ Ross $\square$ C. $\square$ A Ma $\square$ o $\square$ the Shire o $\square$ Du $\square \square$ arton $\square(1777) \square$ ational Archives o $\square$ Scotland RH $\square \square$ 302/20.

${ }^{16}$ Graha $\square \square \square$. General View of the Agriculture of S tirlingshire ( $\square$ din $\square$ urgh: $\square$ oard o $\square$ Agriculture and Internal I $\square \square$ rove $\square$ ent $\square$ 1812).

17 ohnson $\square$ re 66.

${ }^{18}$ e.g. $\square$ S inner $\square \square$.C. $\square$ The Lime Industry in the Lothians ( $\square$ din $\square$ urgh: $\square$ niversity o $\square \square$ din $\square$ urgh De $\square$ art $\square$ ent o $\square$ Adult $\square$ ducation and $\square$ tra Mural Studies $\square$ 1969) $\llbracket$ S $\square$ inner $\square \square$.C. $\square$ The archaeology o $\square$ the li $\square$ e industry in Scotland $\square$ P ost-Medieval Archaeology $\square(197 \square) \square 22 \square 30$.

${ }^{19}$ Coull $\square \square$ R. $\square$ Co $\square \square$ unications and trade in Scottish ar $\square$ ing ro $\square$ the Medieval $\square$ eriod to $1900 \square$ in $\square$ enton $\square$ A. $\square \square$. Veitch (eds.) $\$ Scottish Life and Society, a Compendium of Scottish Ethnology.

Volume 2. Farming and the Land ( $\square$ din $\square$ urgh: $\square$ ohn Donald $\angle 2011) \square 8 \square \square$ or Charlestown $\llbracket$ see Scottish $\mathrm{Li} \square$ e Centre Trust $\square$ Charlestown Limeworks. Research and Conservation ( $\square$ din $\square$ urgh $\square 2006$ ).

${ }^{20} \mathrm{~S} \square$ inner $\square$ re $\square 18 \square \square$ is $\square$ et $\$ S. $\square$ The archaeology o the li $\square$ e industry in Ren rewshire $\square$ Renfrewshire Local History Forum J ournal $\square 13$ (200ロ $\square \square 1$.

$21 \sqsubset$ ohnson $\square$ re $\square 1 \square \square$ is $\sqsubset$ et $\square$ re $\square 20 \square \mathrm{Mac} \square$ ay $\square \square . \square \mathrm{Li} \square$ estone wor $\square$ ing. A orgotten Stirlingshire industry $\square$

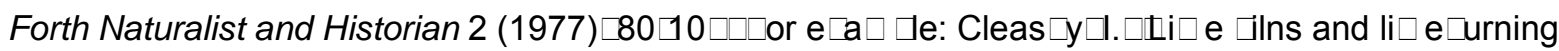
in Sed $\square$ ergh $\square$ Garsdale and Dent $\square$ art $1 \square$ The Sedbergh Historian $\varangle 3: 3$ (1994) $\sqsubset 2 \square 9 \square \mathrm{Li} \square \mathrm{e}$ $\square$ ilns and li $\square$ e $\sqsubset$ urning in Sed $\sqsubset$ ergh $\square$ Garsdale and Dent $\square$ art $2 \llbracket$ The Sedbergh Historian $₫ 3: 4$ (199 $\square) \square 8$.

$22 \square$ isho $\square \square \square$. and G. Tho $\square$ son $\square$ How OS de $\sqcap$ icted li $\square$ e $\square$ ilns in Scotlands Central $\square$ elt $\llbracket$ Sheetlines $\square 98$ (2013) $\square 1931 \square \square$ isho $\square \square \square$. and D. Munro $\square \square$ urther co $\square \square$ ent on OS $\square \mathrm{a} \square$ ing o $\square$ il $\square$ e $\square$ ilns in Scotland $\square$ Sheetlines $\square 101$ (2014) $\square 42 \square \square \square$ isho $\square \square \square$. $\square$ Over coo ing li $\square$ e $\square i l n s ~ \square \square$ Sheetlines $\square 106$ (2016) $\square 323 \square$ Mitchell and $\square$ isho $\square$ re $\square 3$.

${ }^{23}$ Graha $\square$ re $\square 16$.

$24 \square$ ritish Geological Survey $\square$ Glasgow. Scotland Sheet 30E, Solid. 1: $\square 0000$ ( $\square$ ottigha $\square: \square$ ritish Geological Survey $\square$ 1993) $\square \square$ ritish Geological Survey $\square$ Airdrie. Scotland Sheet 31W, Solid. 1: $\square 000$ ( $\square$ ottigha $\square: \square$ ritish Geological Survey $\square 1992) \square$

${ }^{2} \square$ S $\square$ illen $\square \square$. $\square$ As $\sqsubset$ ects o the alu $\square \square$ ining industry a $\square$ out Glasgow $\square$ British Mining $\varangle 9$ (1989) $\square 360$. See also $\square$ assett $\square$ D.A. Geological Excursion Guide to the G lasgow District (Glasgow: Geological Society o $\square$ Glasgow $\square 19 \square 8$ ).

${ }^{26} \mathrm{Ibid}$. $\square \mathrm{Ca} \square \square$ ell $\square$ W.A. $\square$ General and ine inorganic che $\square$ icals $\square$ in Russell $\square$ C.A. (ed.) $\square$ Chemistry, Society and Environment. A New History of the British Chemical Industry (Ca $\square \square$ ridge: The Royal Society o $\square$ Che $\square$ istry $\square 2000) \square 1 \square 796$.

$27 \square$ isho $\square$ and Tho $\square$ son $\square$ re $\square 22 \square \square$ igure 3 .

$28 \square$ isho $\square$ and Tho $\square$ son $\square$ re $\square 22 \square \square$ isho $\square$ and Munro $\square$ re $\square 22$. 
$29 \square$ isho $\square$ and Tho $\square \square$ son $\square$ re $\square 22$.

$30 \square$ elsches $\square$ re $\square 12 \square$ Graha $\square \square$ re $\square 16 \square \square$ nless otherwise stated $\square$ we use the ter $\square$ पaldernoc $\square$ to cover $\square$ aldernoc $\square \square$ arish and the $\mathrm{i} \square \square$ ediately ad acent $\square$ arts o $\square \mathrm{Ca} \square \square$ sie $\square$ arish on the northeastern edge o $\square$ aldernoc $\square \square$ arish. $\mathrm{Ca} \square \square$ sie then $\square$ eans the $\square$ ore central $\square$ arts o $\square \mathrm{Ca} \square \square$ sie $\square$ arish. This $a \square$ roach is sensi $\square$ le in that li $\square$ e $\square$ ilns in $\mathrm{i} \square \square$ ediately ad acent $\square$ arts o $\square \square$ aldernoc $\square$ and $\mathrm{Ca} \square \square$ sie $\square$ arishes (South Craigend in $\square$ aldernoc $\square \square$ arish and Glenwynd in $\mathrm{Ca} \square \square$ sie $\square$ arish) are wor $\square$ ing the sa $\square$ e li $\square$ estone and coal sea $\square$ s. The res $\square$ ective ull na $\square$ es are used (e.g. $\square \mathrm{Ca} \square \square$ sie $\square$ arish) when the individual $\square$ arishes are $\square$ eing re erenced.

$31 \square$ nglish Heritage $\square$ Geophysical Survey in Archaeological Field Evaluation (2nd edition) (Swindon: $\square$ nglish Heritage $\square$ u $\backslash$ ishing $\square 2008$ ).

$32 \square$ ach sedi $\square$ ent sa $\square \square$ le was dissolved using a standard tri acid ( $\mathrm{H} \square \square \square \square \mathrm{O}_{3} \square \mathrm{HCl}$ ) dissolution $\square$ rocedure with added $0.2 \square \mathrm{I} \mathrm{HClO}_{4}$. All sa $\square$ les were then diluted so that their $\square$ easured concentrations ell within the $\quad \square \square \square \square 40 \square \square \square$ cali $\square$ ration line. $3 \square \square \square$ is $\square$ uth was used as an internal standard and $\square$ CR 2 geostandard was used as a $\square$ uality chec $\square$ with re $\sqsubset$ eata $\square$ ility set at $\square \square$. Analyses were done on an Agilent $7 \sqsubset 00$ ce IC $\square$ MS itted with a sel $\square$ as $\square$ irating $\square \square$ A concentric ne $\square$ uliser tuned at $0.1 \square \mathrm{l} / \square \mathrm{n}$. Three $\square$ oints $\square$ er $\square$ ea $\square$ and $1 \square$ or $20 \sqsubset$ er analysis were used to ac $\sqsubset$ uire the data. The sa $\square$ e standard solution o $\square \square$ CR 2 was analysed every ive sa $\square$ les as an internal chec $\square$ to chec $\square$ or instru $\square$ ental drit that was not co $\square\ulcorner$ ensated or $\square$ y the internal standard.

$33 \square \operatorname{ar} \square$ er $\square \square$ G. L. L. $\square \square$ ades $\square$ A. $\square$. Mac $\sqsubset$ en $\square$ ie $\square$ A. $\square$ iri $\square$ a and T. $\square$. $\square$ ailey Watts $\llbracket$ Sta $\square$ le lead isoto $\square$ e record o $\square$ lead $\square$ ollution in Loch Lo $\square$ ond sedi $\square$ ents since 1630 A.D. $\llbracket$ Environmental Science and Technology 30 (1996) 30803 .

$34 \square$ isho $\square \square$. $\square \square$. Mu $\square$ o $\square$ Salinas A. $\square$. Mac $\sqsubset$ en $\square$ ie $\square$. $\square$ ul ord and $\square$ Mc $\square$ i $\square$ in $\square$ The character $\square$ volu $\square$ e and $\mathrm{i} \square \square$ lications o $\square$ sedi $\square$ ent $\mathrm{i} \square$ Counded in $\square$ ill da $\square \mathrm{s}$ in Scotland: The case o $\square$ the $\square$ aldernoc $\square$ Mill da $\square$ in $\square$ ast Dun $\square$ artonshire $\llbracket E$ arth and Environmental Science Transactions of the Royal Society of Edinburgh $\square 101$ (2010) 97110 .

${ }^{\square}$ The wiggle $\square$ atching was underta $\lceil$ en in two se $\square$ arate ways. The irst used a version o the chi $\square$ s $\square$ uared $\left(\chi^{2}\right)$ test ( ollowing Ra $\square$ sey $\square$ C. $\square$. $\square$ van der $\square$ licht $\square \square$ and Weninger $\square \square$. Wiggle $\square$ atching $\square$ radiocar $\square$ on dates $\square$ R adiocarbon $\square 43(2001) \square 3819)^{3} \square$ to assess the it $\sqsubset$ etween the 17 data $\square$ oints o $\square$ the South Craigend total lead $\square$ ro ile (the $\chi^{2}$ tests $\mathrm{O} \square$ served values) and every $\square$ ro ile $0 \square 17$ contiguous data $\square$ oints (the $\chi^{2}$ tests $\square \square$ ected values) $\square$ oving $\square$ rogressively down through the dated Loch Lo $\square$ ond $\square$ roile $\square \square$ ected $\square$ roile 1 in the Loch Lo $\square$ ond data enco $\square$ rassed data $\sqsubset$ oints 117 in those data (calendar years 1990.8 to 1968.7) $\square \square \square$ ected $\square$ ro ille 2 enco $\square$ assed Loch Lo $\square$ ond data $\square$ oints 218 (calendar years 1990. $\square$ to 1967.0) $\square \square \square$ ected $\square$ roile 3 data $\square$ oints 319 (calendar years 1990.0 to $196 \square 1) \square$ and so on down the Loch Lo $\square$ ond $\square$ roile. The $\chi^{2}$ statistic was calculated or the co $\square \square$ arison o the South Craigend $\square \square \square$ roile against each o $\square$ these 7917 data $\square$ oint $\square$ ro iles in the Loch Lo $\square$ ond se $\square$ uence $\square$ ac $\square$ to calendar year 1636. The $\square$ atch $\sqsubset$ etween the Loch Lo $\square$ ond $\square \square$ ected $\square$ roile and the South Craigend $\mathrm{O} \backsim$ served $\square$ roile that gave the lowest $\chi^{2}$ value was udged to $\square e$ the est it and the $\square$ asal age o $\square$ that $\square$ articular Loch Lo $\square$ ond 17 data $\square$ oint $\square$ roile gave the $\square$ asal age o $\square$ the South Craigend in ill. The second a $\square$ roach to the wiggle $\square$ atching used the $\square$ acon so tware to 
$\square$ atch the South Craigend $\square \square \square$ roile to the dated Loch Lo $\square$ ond $\square$ roile ( $\square$ laauw $\square$ M. and $\square$.A. Christen $\square$ $\square$ le $\square \square$ le $\square$ aleocli $\square$ ate age de $\square$ th $\square$ odels using an autoregressive ga $\square \square$ a $\square$ rocess $\square$ Bayesian Analysis $\square 6$ (2011) $\square 4 \square 774$ ). This was underta $\square$ en $\square$ y Dr Maarten $\square$ laauw $\square$ the author o the $\square$ acon

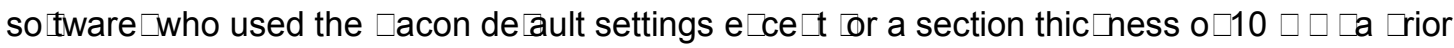
accu $\square$ ulation rate with $\square$ ean 3 and sha $\square$ e $\square$ and using the dated Loch Lo $\square$ ond record as a tailor $\square$ $\square$ ade cali $\square$ ration curve $\square$ against which the South Craigend $\square \square \square$ easure $\square$ ents were wiggle $\square$ atched (Pers. comm. Dr Maarten $\square$ laauw $\square$ anuary $6 \square 2017$ ).

$36 \square$ ritish Geological Survey Mine A $\sqsubset$ andon $\square$ ent $\square$ lan S $\square 188 \square 1 \square \square 17 \square 01$ Woodhead 1.

${ }^{37}$ Pers. comm. e $\square$ ail ro $\square$ David Lawrence $\square \square$ ritish Geological Survey $\square$ din $\square$ urgh $\square 06$ May 2010 $\llbracket$ who also noted that the $\square$ lac $\square$ anded ironstone occurs as the to $\square \square$ ost $\square$ art o $\square$ the coal sea $\square \square$ con ir $\square$ ing that the coal would al $\square$ ost certainly have $\square$ een e tracted to o tain the ironstone.

${ }^{38}$ Radcli $\square$ e $\square \square \square$ On $\square$ urning li $\square$ e with $\sqsubset$ eat $\square$ Prize Essays and Transactions of the Highland Society of Scotland 2 (1803) $\square 1603 \square$ ohnson $\square$ re $\square 6$.

${ }^{39}$ G lasgow Courier 23 May 1822.

${ }^{40}$ Glasgow Herald $\sqsubset 4$ March $18 \sqsubset 0$.

${ }^{41}$ Logan $\square \square$. $\square$ South Craigend and Cornhill: Reading the ruins $\square$ Vernacular Building $\square 38$ (20141 $\square \square \square$ $\square$. The whole o $\square$ the $\square$ receding $\square$ aragra $\square$ draws heavily on this re erence.

42 The lac $\square$ o $\square$ sur ace $\square$ or $\square$ hological evidence or these $\square$ iln re $\square$ nants $\square$ ro $\square$ a $\square$ ly also $\square$ artly re lects decades $\sqsubset$ and $\sqsubset$ erha $\square$ s centuries $\square$ o $\square$ loughing over o $\square$ that to $\square$ ogra $\square$ hy $\square$ as well as the 19th century du $\square$ ing o $\square$ Glasgow city ru $\square$ ish on the agricultural land on Glasgows $\square$ eri hery. (McGuire $\square$. $\square$ G west for a wife: Family farming in West Central Scotland 1850-1930 $\square$ niversity o $\square$ Glasgow $\square$ hD thesis (2012)). Many solid ite $\square$ s ro $\square$ household waste can still $\sqsubset$ e $\square$ ic $\sqsubset$ ed $u$ u around the $\square$ ilns in the $\square$ oghall ield $\square$ including $\square$ ro $\sqsubset$ en $\sqsubset$ orcelain dolls $\square$ other $\square$ ro $\square$ en cera $\square$ ic igurines $\square$ and rag $\square$ ents o $\square$ what $\mathrm{a} \square$ ears to $\square$ e 19th century do $\square$ estic $\square$ ottery. The du $\square$ ing o $\square$ ru $\square$ ish has $\square$ ro $\square$ a $\square$ ly served to raise the ground sur $a$ ace around and in the $\square$ ilns $\square$ and hence to su $\square$ due the $\square$ iln $\square$ or $\square$ hology $\square \square$ ecause $\square$ odern $\square$ loughing turns $\mathrm{u} \square$ only the ire reddened and $\square$ a $\ulcorner$ ed $\square$ iln $\sqsubset$ eri $\square$ eters and not the $\square$ iln toor ( $\square$ igure $\square$ ). ${ }^{43}$ See $\square$ igure 3 o $\square$ Mac $\square$ ay $\square$ re $\square 21 \square$ Harrison $\square$ re $\square 11 \square 87$.

${ }^{44}$ We have not yet seen any $\square \mathrm{a} \square \square$ ing that shows Red $\square$ iln $\square$ ut the order o $\square$ data in the census i $\square \square$ lies that it was close to $\square$ an $\sqsubset$ ier.

${ }^{4} \square \mathrm{Si} \square$ o $\square$ the Hole coal $\square$ iners were ro $\square$ the sa $\square$ e $a \square$ ily $\square$ na $\square$ ely $\square$ ohn Marshall and ive o $\square$ his sons $\square$ the youngest aged only 9 years old.

$46 \square$ isho $\square$ and Tho $\square$ son $\square$ re $\square 22$.

${ }^{47} \operatorname{Logan} \square$ re $\square 41$.

$48 \mathrm{Ibid}$.

${ }^{49}$ A Royal Co $\square \square$ ission on the Ancient and Historical Monu $\square$ ents o $\square$ Scotland $\mathrm{i} \square$ age o $\square$ the Sculliongour ( $\square$ algrochan) cla $\square \square$ Gilns is given on Scran with the ollowing ID: 000 000 18 $\square 187$ C. 0 The 1630 lease noted in re $\square 11 \square \mathrm{a} \square$ es it clear that $\square$ algrochan is a long standing na $\square \mathrm{e}$ in the $\square$ aldernoc $\square \mathrm{li} \square \mathrm{e}$ industry. The lease na $\square$ es Carlestoun $\square$ which is in the area treated here as 
$\square$ aldernoc $\square$ is ad acent to $\square$ aster and Wester $\square$ algrochan (though technically these areas are in $\mathrm{Ca} \square \square$ sie $\square$ arish).

$\square 1 \mathrm{Mr}$ Reid Harrison pers. comm. Dece $\square$ ¿er 2014.

2 Lanar $\square$ Sheet 6.2 (Maryhill) $\llbracket$ surveyed 18 $\square \square$ u $\square$ lished 186 $\square$ Stirling

Sheet 30.6 ( $\square$ al $\square \mathrm{ir} \square) \square$ surveyed $1860 \square \square$ ulished 1864 .

$3 \square$ ow $\square$ an $\square$ re $\square 13 \square 48$.

${ }^{4}$ Harrison $\square$ re $\square 11 \square \mathrm{Mc} \square$ ay $\square$ re $\square 21$.

$\square$ Woodhead $\square$ state Archives $\square$ Mitchell Li $\square$ rary Glasgow $\square \operatorname{TL} \square / 6 / 2 / 1$.

$6 \sqsubset$ ohnson $\square$ re $\square \square \square 127$.

$\square$ Car $\square$ ichael $\square$ re $\square 4 \square 6 \square$

8 OS $2^{\text {nd }}$ edtion 1:2 $\square 0 \square \mathrm{a} \square \square$ ing $\square u \square \square$ artonshire sheet $23.11 \square$ revised 1896 $\square$ u $\square$ lished 1898

${ }^{9}$ Ward $\square$ T. $\square \square$ raehead Village $\$ South Lanar $\_$shire: a survey and historical review $\llbracket$ Biggar

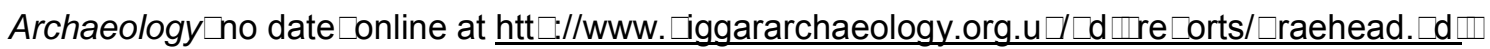
accessed ־uly 22־2013

$60 \square$ is $\square$ et $\square$ re $\square 20$.

61 htt $\sqsubset: / /$ www.geogra $\square$ h.org.u $\square$ /article/West Dun $\square$ artonshire $L i \square$ estone Industry $\square$ etwor $\square$ accessed anuary 23 2017. See also Mitchell $\square \square \square$ Cornstone $\square$ urning or ertili er in eighteenth century

Du $\square \square$ artonshire and Stirlingshire $\square$ S cottish Local History $\llbracket 8 \square(2013) \square 434 \square$.

62 Diro $\square \square$ no initial $\square$ lan and descrition o $\square$ li $\square$ e $\llbracket$ ilns $\square$ P rize Essays and Transactions of the Highland Society of Scotland 3 (1807) $\square 1107$.

63 Scottish Li $\square$ e Centre Trust $\square$ re $\square 19$.

$64 \square \mathbf{a} \leftarrow$ ton $\square$ R. and $\square$ Shi $\square$ way $\square$ Civil Engineering Heritage: Scotland - Lowlands and Borders (Tho $\square$ as Tel ord Ltd) 349 .

$6 \square$ Scottish Li $\square$ e Centre Trust $\square$ re $\square 19$.

66 Wallace $\square \square \square$ Account o $\square$ the $\square$ ethod o $\square$ calcining li $\square$ estone in so $\square$ e o $\square$ the li $\square$ estone $\square$ uarries in Scotland $\square$ Transactions of the Highland and Agricultural Society of S cotland $\square$ ew Series $\square \square(1837) \square$ $441 \square[$.

${ }^{67}$ Tac $\square$ dated $\square$ e $\square$ ruary 26 1813. Woodhead Archives $\square$ Mitchell Li $\square$ rary Glasgow TL $\square$ 6/2/1.

$68 \sqsubset$ ohnson $\square$ re $\square 1$.

$69 \square$ ohnson $\square$ re $\square 6$.

$70 \mathrm{Car} \square$ ichael $\square$ re $\square 4$. 
Table 1. $\square \mathbf{u} \square \square$ ers o $\square$ ilns in $\square$ aldernoc $\square$ and $\mathrm{Ca} \square \square$ sie ro $\square$ OS $\square \mathrm{a} \square$ ing su $\square \square \mathrm{le} \square$ ented $\square \mathrm{y}$ ield chec $\square$ ing. All $\square$ ilns re $\square$ orted here are cla $\square \square$ ilns and no draw $\square$ ilns have $\square$ een either $\square$ a $\square$ ed $\square$ y OS or identilied in our ield $\square \mathrm{a} \square$ ing. Re Rer to $\square$ igure 2 or locations.

\begin{tabular}{|c|c|c|c|}
\hline $\begin{array}{l}\text { Locality; } \\
\text { guide GR and } \\
\text { Fig reference } \\
\text { (if relevant) }\end{array}$ & $\begin{array}{c}\text { Area } \\
\text { (Parish) }\end{array}$ & $\begin{array}{l}\text { Number } \\
\text { of kilns }\end{array}$ & $\begin{array}{l}\text { Other lime-related features from OS mapping, field } \\
\text { checking, census data, archives etc }\end{array}$ \\
\hline $\begin{array}{l}\square 1 . \square \text { oghall } \square \\
\square \mathrm{S} \square 7974 \square \\
\square \text { igure 3 }\end{array}$ & $\begin{array}{c}\square \text { aldernoc } \square \\
\text { ( } \square \text { aldernoc } \square \text { ) }\end{array}$ & 17 & 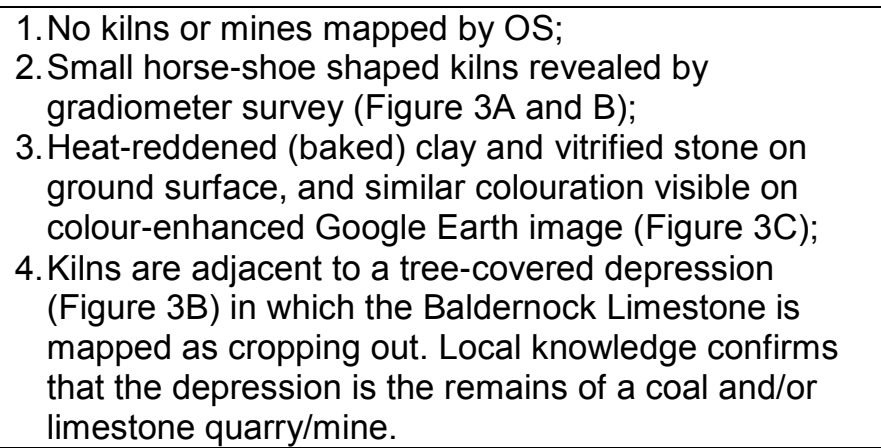 \\
\hline $\begin{array}{l}\text { 2. } \square \text { th } \\
\square \text { ardowie } \square \\
\square \mathrm{S} \varangle 1749\end{array}$ & $\begin{array}{c}\square \text { aldernoc } \square \\
\text { ( } \square \text { aldernoc } \square \text { ) }\end{array}$ & $\square$ & 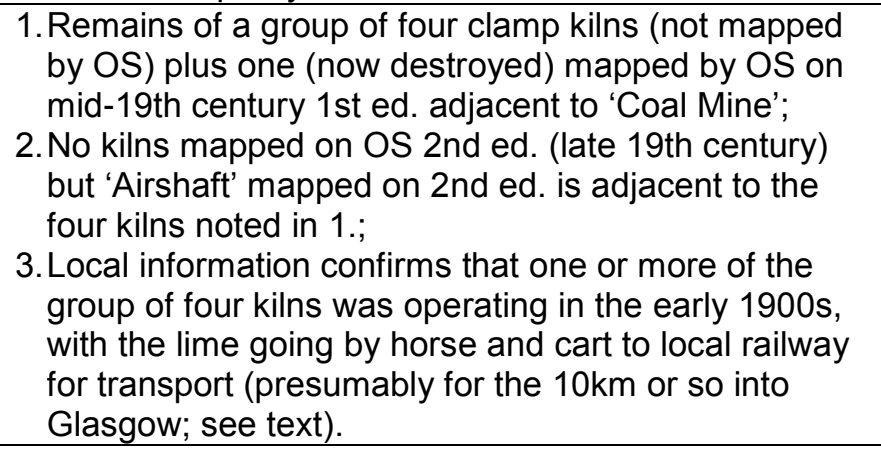 \\
\hline $\begin{array}{l}\text { 3. Hole } \square \\
\square \text { S60 } \square 72 \\
\square \text { igure } 4\end{array}$ & $\begin{array}{c}\square \text { aldernoc } \square \\
\text { ( } \square \text { aldernoc } \square \text { ) }\end{array}$ & 11 & $\begin{array}{l}\text { 1. All OS mapped kilns labelled as 'Old Limekilns' } \\
\text { ( } \square \text { igure 4) } \square \\
\text { 2. Multiple mines ('Old Pit'; 'Old Pit Coal \& Limestone'; } \\
\text { 'Limestone Pit'; 'Coal \& Limestone Pit' [the latter two } \\
\text { la } \square \text { els } \square \text { lacking 'Old', i } \square \square \text { पying active } \square \text { ining when OS } \\
\text { surveyed the area in 1860 } \square \\
\text { 3. Re } \square \text { ains o } \square \text { elevated (constructed) ridge or tra } \square \text { way } \\
\text { ro } \square \square \text { ine entrance to } \square \text { ilns ( } \square \text { igure 4) } \\
\text { 4. Downhill terminus of 'South Craigend Lime Road' } \\
\text { ( } \square \text { igures } 4 \text { and 9). }\end{array}$ \\
\hline $\begin{array}{l}\square 4 . \operatorname{Linn} \square \\
\square \mathrm{S} \square 907 \square 6\end{array}$ & $\begin{array}{l}\square \text { aldernoc } \square \\
\text { ( } \square \text { aldernoc } \square \text { ) }\end{array}$ & 1 & $\begin{array}{l}\text { 1. Single } \square \text { iln ad acent to a ( } \square \text { resu } \square \text { a } \square \text { ly li } \square \text { estone) } \\
\square \text { uarry or } \square \text { ine } \square \\
\text { 2. } \square \text { nla } \square \text { elled on OS 1st ed. 6" mapping, but 'Old } \\
\text { Limekiln' on OS 1st ed. 25" and OS 2nd ed. 6" } \\
\square \text { a } \square \square \text { ing } \square \\
\text { 3. A } \square \text { a or underground li } \square \text { estone } \square \text { ine (the } \square \text { aldernoc } \square \\
\text { Linn Mine) is also ad acent } \square \\
\text { 4. House 'Linn' mapped adjacent to the quarry and kiln } \\
\text { on OS 1st ed.; this is presumably the 'Linn Bank' } \\
\text { occu } \square \text { ied } \square \text { a li } \square \text { e } \square \text { iner and his a } \square \text { ily in the 18 } \square 1 \\
\text { census } \square \\
\square \square \text { nrooed house } \square \text { a } \square \text { ed on OS 2nd ed. }\end{array}$ \\
\hline $\begin{array}{l}\square \text { South } \\
\text { Craigend } \square \\
\square \text { S602760 } \\
\square \text { igure }\end{array}$ & $\begin{array}{c}\square \text { aldernoc } \square \\
\text { ( } \square \text { aldernoc } \square \text { ) }\end{array}$ & 37 & $\begin{array}{l}\text { 1. All kilns labelled as 'Old Limekilns' on OS 1st and } \\
\text { 2nd eds } \square \\
\text { 2. Subsurface 'plumbing' connecting clamp kilns } \\
\text { indicated on gradio } \square \text { eter survey ( } \square \text { igure } \square \square \text { ) } \\
\text { 3. Multi } \square \text { le } \square \text { ine sha ts (identi ied in ield and not } \\
\square \text { a } \square \text { ed } \square \text { y OS } \square \text { central } \square \text { ine entrance } \square \text { a } \square \square \text { ed on } \\
\square \text { ine a andon } \square \text { ent } \square \text { an } \square \text { igure } 8) \square \\
\text { 4. } \square \square \text { hill ter } \square \text { inus of 'South Craigend Lime Road' } \\
\text { ( } \square \text { igure 9). }\end{array}$ \\
\hline
\end{tabular}




\begin{tabular}{|c|c|c|c|}
\hline $\begin{array}{l}\text { 6. } \square \text { lairs } \text { aith } \\
\text { Trig } \square \\
\square \text { S } \square 6767 \\
\square \text { igure } 6\end{array}$ & $\begin{array}{c}\square \text { aldernoc } \square \\
\text { ( } \square \text { aldernoc } \square \text { ) }\end{array}$ & $\begin{array}{l}26 \\
\text { ( } \square \text { ini } \square \text { u } \square \\
\square \text { ecause } \\
\square \text { arts o } \square \\
\text { this area } \\
\text { are highly } \\
\text { distur } \square \text { ed } \\
\square \text { y later } \\
\text { orestry } \\
\text { activities) }\end{array}$ & 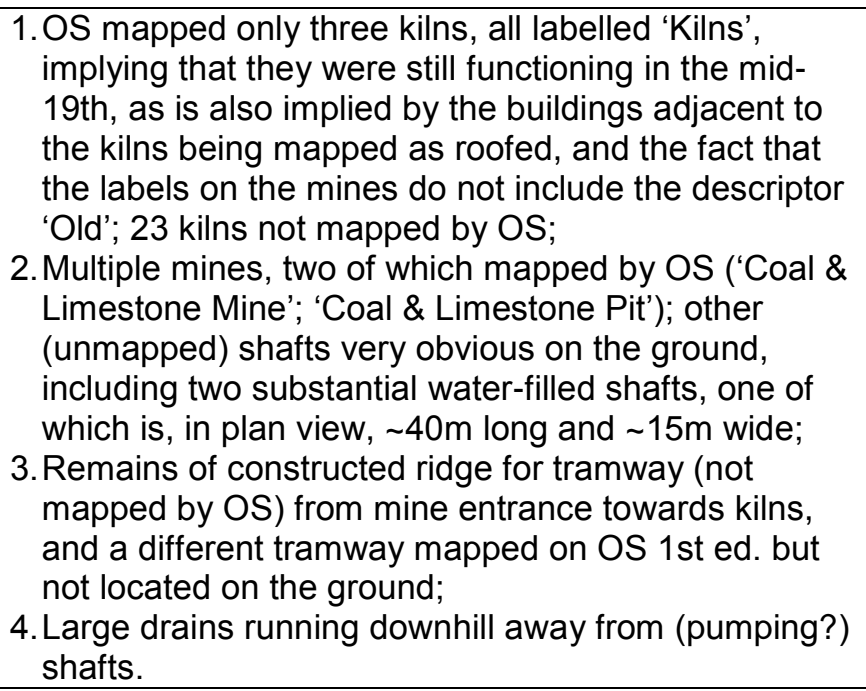 \\
\hline $\begin{array}{l}\text { 7. Glenwynd } \square \\
\square \text { S606761 } \\
\square \text { igure } 7\end{array}$ & $\begin{array}{l}\square \text { aldernoc } \square \\
(\mathrm{Ca} \square \square \text { sie })\end{array}$ & 24 & $\begin{array}{l}\text { 1. All OS mapped kilns labelled as 'Old Limekilns'; } \\
\text { 2.Nine mines (all 'Old Pit Coal \& Limestone') mapped } \\
\square \text { y OS in area i } \square \square \text { ediately surrounding these } \square \text { ilns } \square \\
\text { with other un } \square \text { a } \square \text { ed } \square \text { ines and/or air sha ts located } \\
\text { in ield chec } \square \text { ing and/or } \square \text { a } \square \square \text { ed } \square \text { y OS as s } \square \text { all } \\
\text { circular } \square \text { onds } \square \\
\text { 3. Glenwynd } \square \text { ar } \square \text { house is u } \square \text { hill ter } \square \text { inus o o } \square \\
\text { 'Glenwynd Lime Road' ( } \square \text { igure 9). }\end{array}$ \\
\hline $\begin{array}{l}\text { 8. Langshot } \square \\
\square \text { S61 } \square \square 8\end{array}$ & $\begin{array}{l}\square \text { aldernoc } \square \\
\text { (Ca } \square \square \text { sie) }\end{array}$ & 6 & $\begin{array}{l}\text { 1. All OS mapped kilns labelled as 'Old Limekilns'; } \\
\text { 2. On side branch of 'Langshot Lime Road’ ( } \square \text { igure 9). }\end{array}$ \\
\hline $\begin{array}{l}\text { 9. Culloch } \\
\text { Sla } \square \\
\square \text { S622773 } \\
\text { igure } 12\end{array}$ & $\begin{array}{l}\mathrm{Ca} \square \square \text { sie } \\
(\mathrm{Ca} \square \square \text { sie })\end{array}$ & $\begin{array}{l}\text { 1st ed.: } 7 \\
\text { 2nd ed.: } \\
\square\end{array}$ & $\begin{array}{l}\text { OS 1st edition: } \\
\text { 1. Mapped as 'Limekilns' on OS } 1 \text { st ed 6" map and as } \\
\text { 'Old Limekilns' on OS } 1 \text { st ed } 25 \text { " map; } \\
\text { 2. } \square 1 \square \square \text { long tra } \square \text { way } \square \text { a } \square \text { ded connecting } \square \text { ilns to } \\
\text { 'Culloch Slap Old Mine Coal \& Limestone'. } \\
\text { OS 2nd edition: } \\
\text { 3. } \square \text { ilns re } \square \text { uilt } \square \\
\text { 4. Mapped as 'Limekilns' and there ore assu } \square \text { ed to } \square \text { e } \\
\text { o } \square \text { erating } \square \\
\square 1 \square \square \text { long tra } \square \text { way still } \square \text { resent and a second } \\
\text { tra } \square \text { way } \square 00 \square \text { long to a new (second) } \square \text { ine is } \\
\square a \square \text { ed. }\end{array}$ \\
\hline $\begin{array}{c}\square \text { 10. Ca } \square \text { s } \square \text { ie } \\
\text { Alu } \square \text { Wor } \square \text { s } \square \\
\square \text { S632770 }\end{array}$ & $\begin{array}{l}\mathrm{Ca} \square \square \text { sie } \\
(\mathrm{Ca} \square \square \text { sie })\end{array}$ & $\begin{array}{c}\text { 1st ed.: } 8 \\
\text { 2nd ed.: } \\
\quad 8\end{array}$ & $\begin{array}{l}\text { OS 1st edition: } \\
\text { 1. Mapped as 'Limekilns' on 1st ed 6" and 25" maps; } \\
\text { 2. Two tra } \square \text { ways connecting } \square \text { ilns to } \square \text { ines: one } \square \square 0 \\
\square \text { long to 'Coal \& Limestone Mine' } \square \text { and the other } \square \\
960 \text { m long to 'Tarfin Mine (Alu } \square \text { Coal } \square \\
\text { Li } \square \text { estone)'. } \\
\text { OS 2nd edition: } \\
\text { 3. } \square \text { ilns re } \square \text { uilt } \square \text { rearranged and enlarged (two } \square \text { a } \square \square \text { ed } \\
\text { as } \square \text { eing } \square 17 \square \text { long) } \square \\
\text { 4. } \square 0 \square \text { long tra } \square \text { way still connecting to irst } \square \text { ine } \\
\text { noted under 1st edition, now called 'Boydsburn } \\
\text { Mine'. }\end{array}$ \\
\hline $\begin{array}{l}\square 11 . \square \text { aldoran } \\
\text { (Derry Coal } \square \\
\text { Li } \square \text { e Wor } \square \text { s } \\
\text { on 1st ed. } \square \\
\text { Glorat Li } \square \text { e } \\
\text { Wor } ₫ \text { s on 2nd } \\
\text { ed) } \square \\
\square \text { S6 } \square 0772 \\
\square \text { igure } 13\end{array}$ & $\begin{array}{l}\mathrm{Ca} \square \square \text { sie } \\
(\mathrm{Ca} \square \square \text { sie })\end{array}$ & $\begin{array}{l}\text { Derry: } 11 \\
\text { Glorat: } \\
13\end{array}$ & 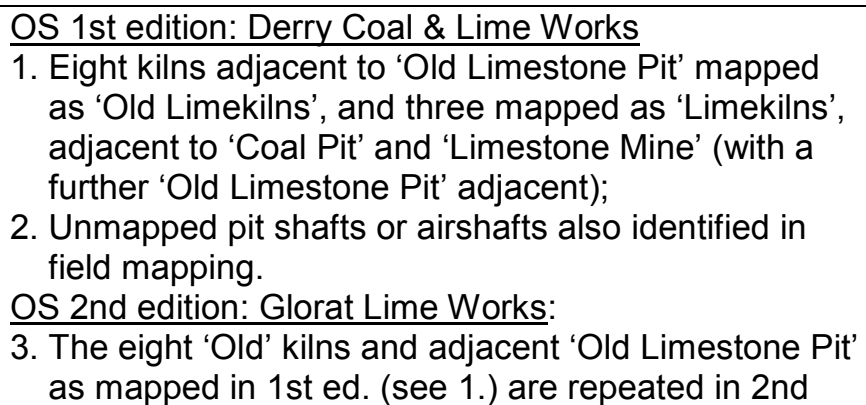 \\
\hline
\end{tabular}




\begin{tabular}{|c|c|c|c|}
\hline & & & $\begin{array}{l}\text { ed. } \square \\
\text { 4. } \square \text { ive large } \square \text { ilns have re } \square \text { laced the three 'limekilns' } \\
\square a \square \text { ed in 1st ed. } \square \\
\square . \text { Tramway and roadway into 'Levels' (adits) } \square \text { airshatt } \square \\
\text { plus 'Old Limestone Pit'; } \\
\text { 6. } 600 \square \text { long tra } \square \text { way connecting the Glorat Li } \square \text { e } \\
\text { Works to the North British Railway's Blane Valley } \\
\square \text { ranch line (including a } \square \text { ridge to cross the Gla }\ulcorner\text { ert } \\
\text { Water). }\end{array}$ \\
\hline $\begin{array}{c}\square \text { 12. Glorat } \\
\text { House Coal } \square \\
\text { Li } \square \text { e Wor } \square \text { s } \\
\text { (1st ed.) } \square \\
\square \text { S644781 }\end{array}$ & $\begin{array}{c}\mathrm{Ca} \square \square \text { sie } \\
(\mathrm{Ca} \square \square \text { sie })\end{array}$ & $\begin{array}{c}\text { 1st ed.: } \\
\text { 2nd ed.: } \\
0\end{array}$ & 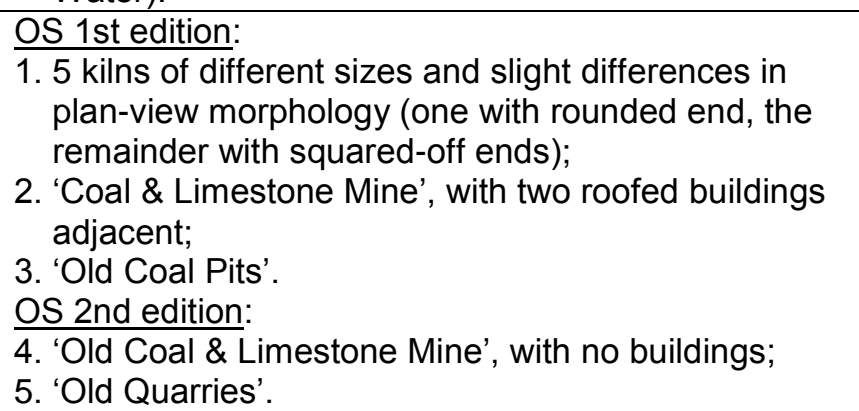 \\
\hline $\begin{array}{c}\square 13 . \\
\text { Sculliongour } \\
\text { Li } \square \mathrm{e} \square \text { Coal } \\
\text { Wor } \square \square \\
\square \mathrm{S} 626790\end{array}$ & $\begin{array}{c}\mathrm{Ca} \square \square \text { sie } \\
(\mathrm{Ca} \square \square \text { sie })\end{array}$ & $\begin{array}{l}\text { 1st ed.: } \\
\text { 2nd ed.: } \\
\quad 8\end{array}$ & $\begin{array}{l}\text { OS 1st edition: } \\
\text { 1. 'Mines', 'Old Coal Pits'. } \\
\text { OS 2nd edition: } \\
\text { 2. } \square \text { ilns re } \square \text { uilt } \square \text { reorganised } \square \text { and a } \square \text { arently increased } \\
\text { in si } \bullet \text { e and nu } \square \square \text { er o } \square \square \text { ilns } \square \\
\text { 3. 'Levels'; } \\
\text { 4. More than } 800 \square \text { o } \square \text { tra } \square \text { ways } \square \text { etween levels and } \\
\quad \square \text { ilns } \square \\
\square . \text { Roo ed } \square \text { uilding ad acent to } \square \text { ilns. }\end{array}$ \\
\hline
\end{tabular}


$\square$ isho $\square$ et al. $\square \mathrm{i} \square$ e $\square$ urning in cla $\square \square \square$ ilns $\square$ Scotland's western Central $\square$ elt

Table 2. $\square \mathrm{u} \square \square$ ers e $\square \square$ loyed in the li $\square$ e and coal industries in $\square$ aldernoc $\square$ and $\mathrm{Ca} \square \square$ sie $\square$ arishes according to various 19 th century censuses

\begin{tabular}{|c|l|c|c|}
\hline & Census & $\square$ aldernoc $\square \square$ arish & Ca $\square \square$ sie $\square$ arish \\
\hline Li $\square$ e & 1841 & 14 & $3 \square$ \\
\hline & $18 \square 1$ & 6 & 29 \\
\hline & 1861 & 1 & 22 \\
\hline & 1871 & 0 & $\square 4$ \\
\hline & & 12 & 70 \\
\hline Coal & 1841 & 7 & 118 \\
\hline & $18 \square 1$ & 14 & 118 \\
\hline & 1861 & 7 & 143 \\
\hline
\end{tabular}

$\square$ ote: The 1841 and $18 \square 1$ census data were o $\square$ tained ro $\square$ www. reecen.org.u $\square$ and the data or the 1861 and 1871 censuses were derived ro $\square$ the $\square$ icroil $\square$ co $\square$ ies o the original census enu $\square$ erator $\square$ oo $\square$ s held $\square$ y the $\square$ ast Dun $\square$ artonshire Leisure and Culture Trust at Willia $\square \square$ atric $\square$ Li $\square$ rary $\square$ $\square$ ir $\square$ intilloch. The $\square$ icro $i$ il $\square$ reader at the Willia $\square \square$ atric $\square$ Li $\square$ rary was $\square$ rovided $\square$ y the $\square$ ews $\square$ a $\square$ er 2000 $\square$ ro ect $\square$ the Heritage Lottery $\square$ und $\square$ and the Regional $\square$ ews $\square$ a $\square$ er Industry. 
Figures:

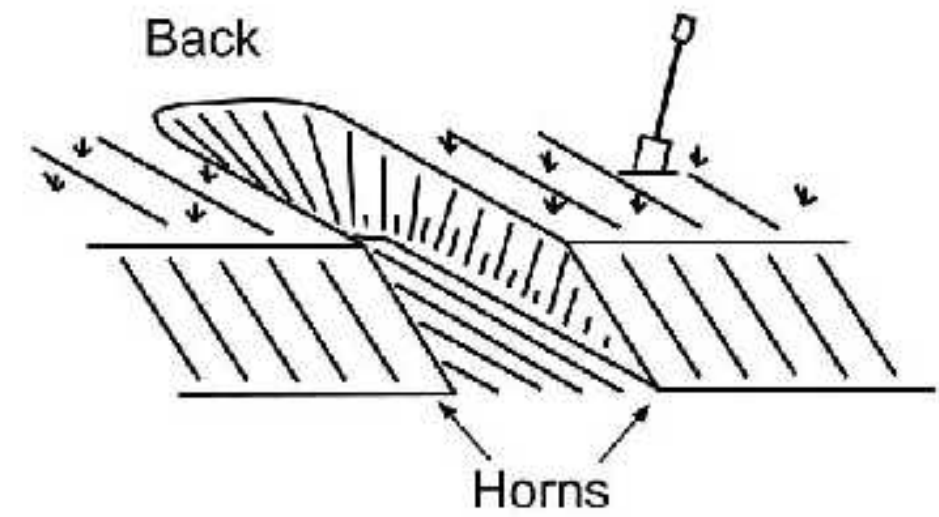

A.

B.
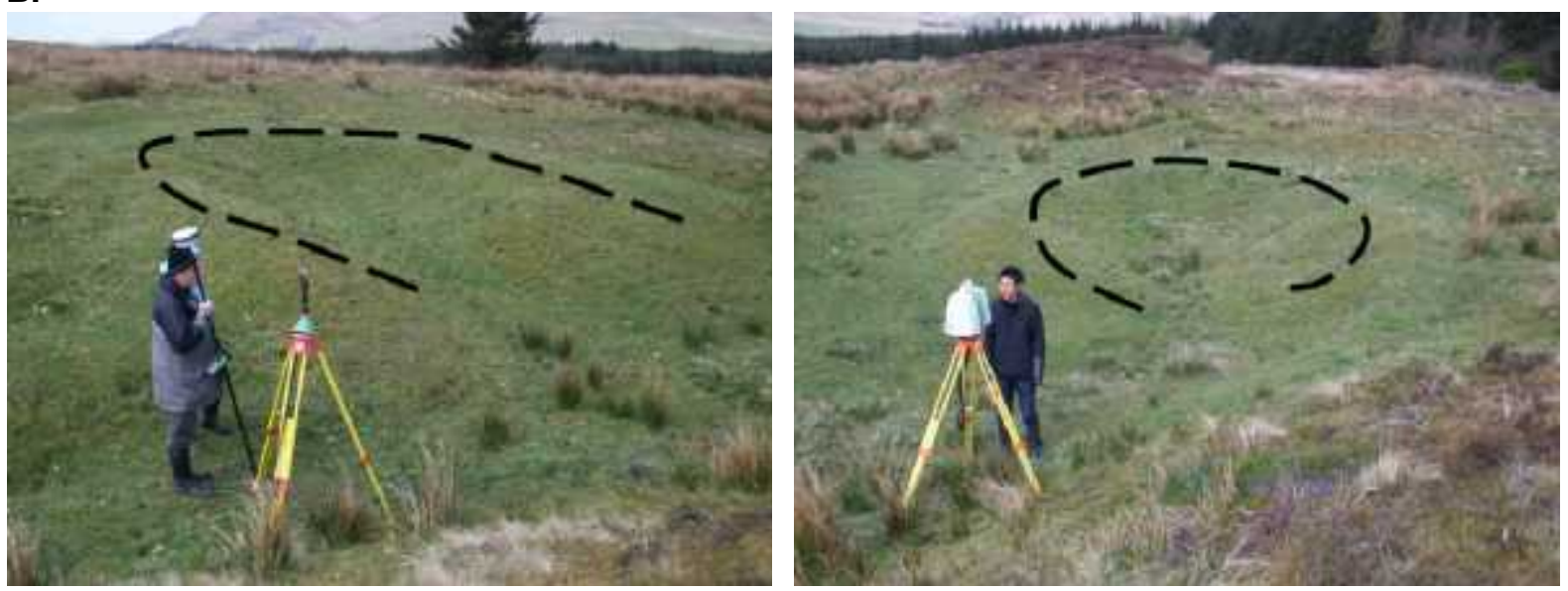

Figure 1. A. S $\square$ etch o $\square$ cla $\square \square$ Ciln redrawn $\square$ y $\square$ isho $\square$ ro $\square \square$ is $\square$ et $\square$ S. $\square$ re $\square 3 \square \square$ igure 1. $\square$. Degraded re $\square$ ains o $\square$ cla $\square \square$ ¿ilns at $\square$ lairs $\square$ aith Trig $\square \square$ aldernoc $\square$ (lett: $\square$ sha $\square$ ed $\square$ iln $\square$ and right: adacent horseshoe sha $\square$ ed $\square$ iln $\square$ oth at centre $\mathbb{l e}$ t o $\square \square$ igure 6 see $\square$ igure 2 or location and detail).

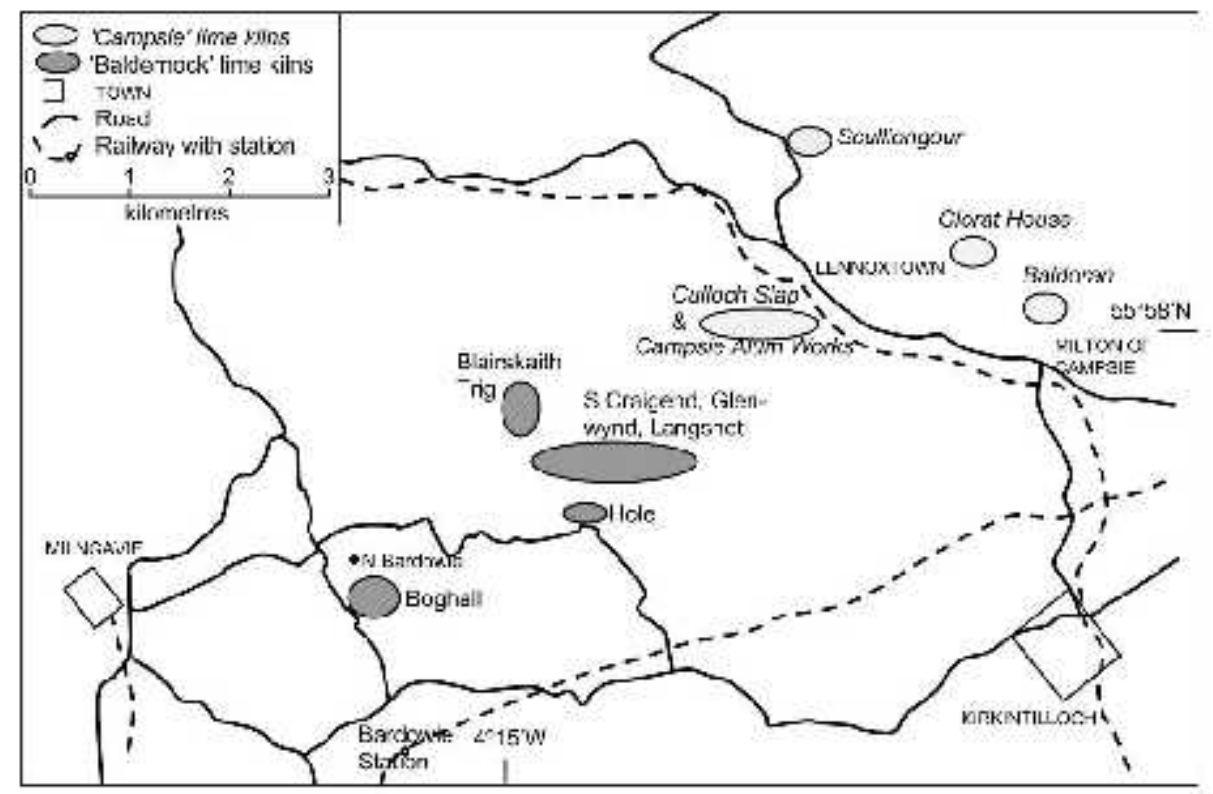

Figure 2. Ma $\square$ o the $\square$ rinci $\square$ al li $\square$ e $\square$ iln sites in $\square$ aldernoc $\square$ and Ca $\square \square$ sie $\square$ arishes. The South Craigend $\sqsubset$ ilns lie in $\square$ aldernoc $\square \square$ arish. The ad acent Glenwynd and Langshot $\sqsubset$ ilns are in Ca $\square \square$ sie 
$\square$ arish $\square$ ut they are treated here together as $\square$ art o $\square$ the $\square$ aldernoc $\square$ li $\square$ e $\square$ ilns $\square$ ecause they are clearly wor $\square$ ing the sa $\square$ e occurrence o the $\square$ aldernoc $\square \mathrm{Li} \square$ estone and its associated coal.

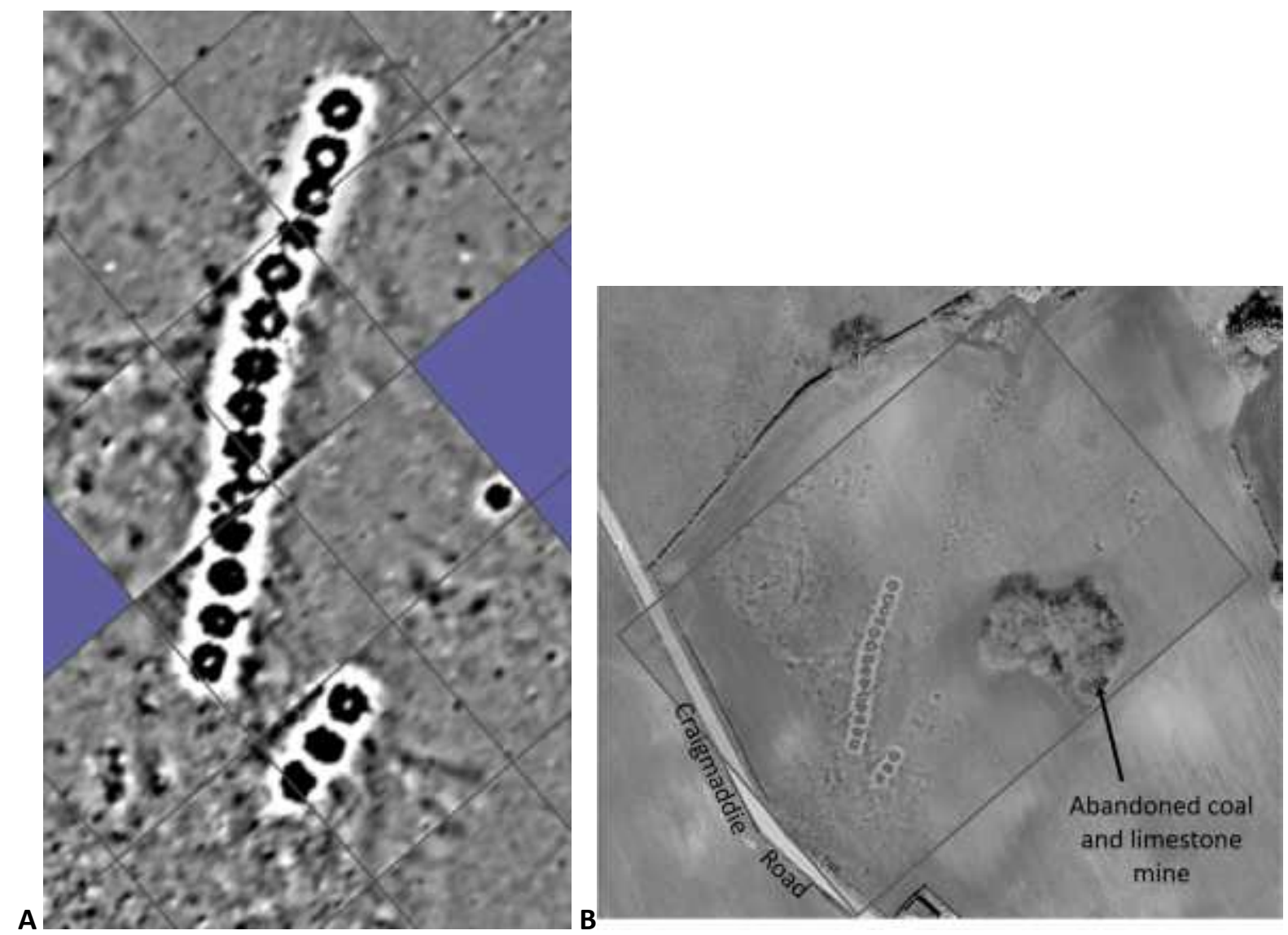

C.

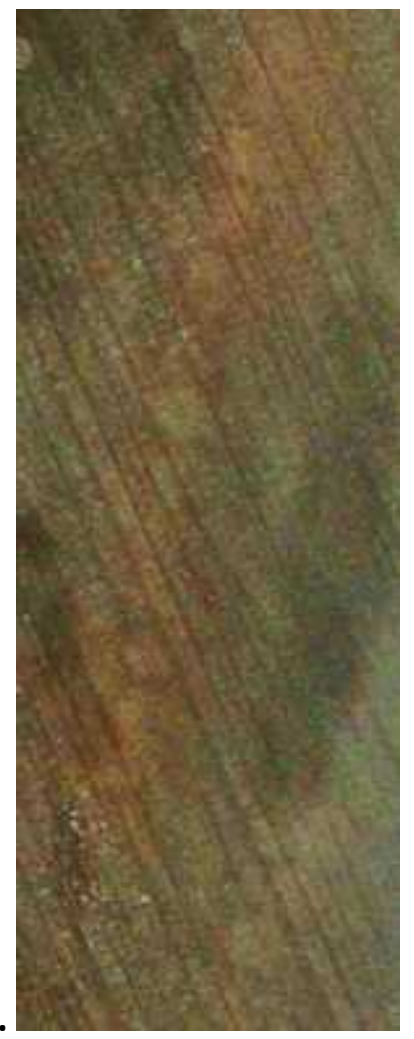

Figure 3. $\square$ oghall li $\square$ e $\square$ ilns. A. Gradio $\square$ eter survey showing the re $\square$ ains o $\square 17$ horseshoe sha $\square$ ed cla $\square \square$ illns. $\square$. The $\square$ oghall $\square$ ilns as revealed $\square$ y gradio $\square$ eter survey in conte $\leftarrow$ thighlighting the $\square i l n s \square$ 
closeness to the ad acent $\square$ ine in the $\square$ aldernoc $\square$ Li $\square$ estone and associated coal $\square$ easures. C. Colour $\square$ and contrast enhanced aerial $\square$ hotogra $\square h$ highlighting the circular reddened $\square$ urnt ground re $\square$ nants corres $\square$ onding to the $\square$ agnetic ano $\square$ alies in A and $\square$.

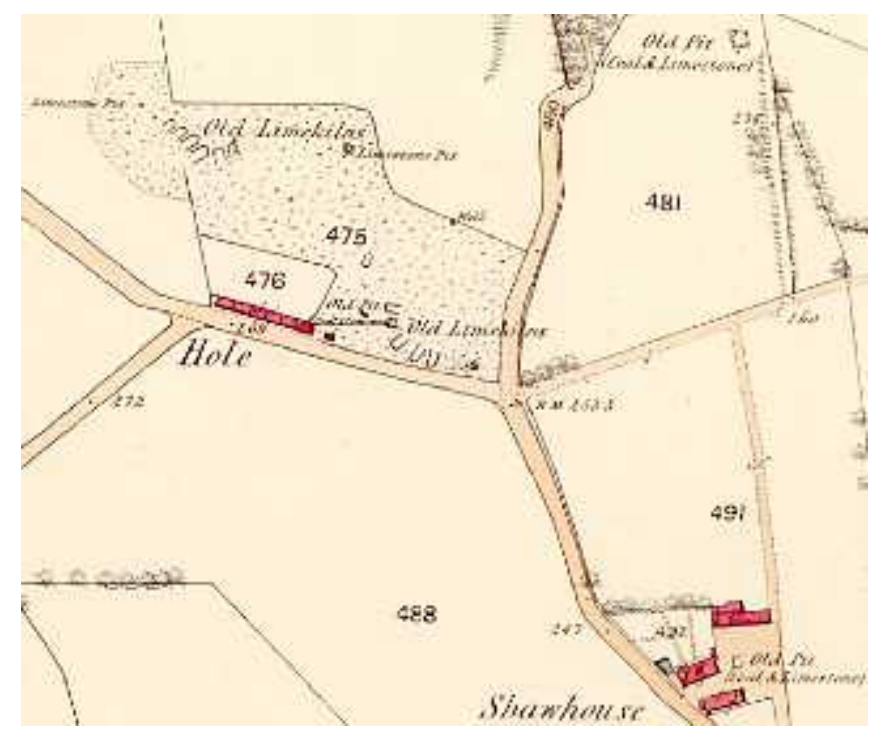

Figure 4. OS 1st edition $2 \square$ inch $\square \mathrm{a} \square$ ing o $\square$ li $\square$ e industry re $\square$ ains at Hole (Stirling Sheet 32.4 ( $\square$ aldernoc $\square \square$ arish) $\square$ survey date $1860 \square u$ u lication date 1864). The elevated ridge at u $\square$ er right is inter $\square$ reted to have carried a tra $\square$ way ro $\square$ old $\square$ it in u $\square$ er right hand corner. A second un $\square a \square$ ed elevated ridge (i.e. $\square$ second tra $\square$ way) ran $\square$ ro $\square$ the southern end o $\square$ the irst tra $\square$ way (at $\mathbf{s} \square$ ot height 260) WSW along the $\square \mathrm{a} \square \square$ ed trac $\square$ to the cross $\square$ road in the $\square$ iddle o $\square$ the $\square$ igure ( $\square$ ar $\square$ ed $\square . M .2 \backsim 3.3)$. That tra $\square$ way would have then continued on to the ilns ad acent to the uildings ( $\square$ iners $\square$ cottages) at Hole. The road co $\square$ ing in ro $\square$ the north west i $\square \square$ ediately to the west o $\square$ Hole is the downhill ter $\square$ inus o the South Craigend Li $\square$ e Road $($ see also $\square$ igure 9). (Re $\square$ roduced $\square \mathrm{y}$ $\ulcorner$ er $\square$ ission o $\square$ the $\square$ ational Li $\square$ rary o $\square$ Scotland)

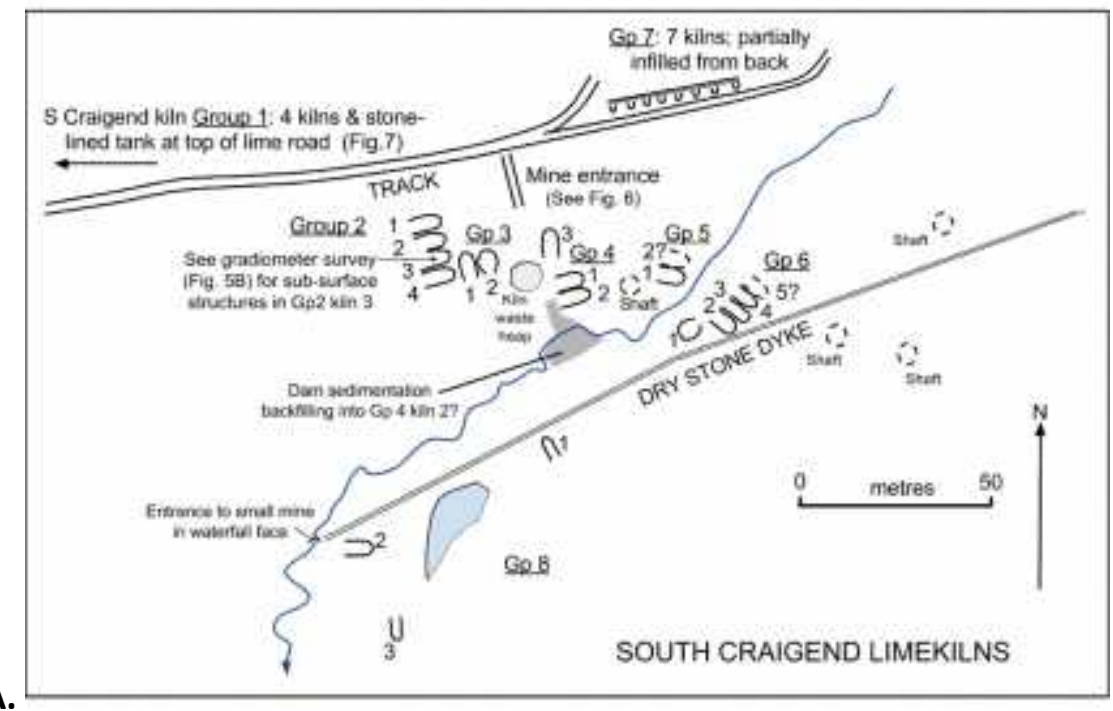

A. 
B.

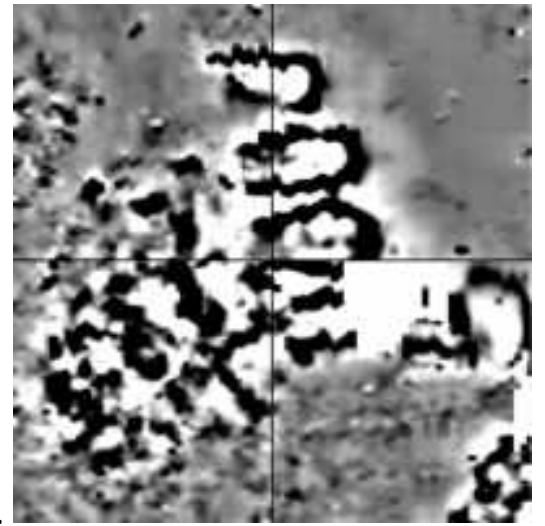

Figure 5. A. Re $\square$ ains o $\square$ the li $\square$ e industry at South Craigend $\square$ ased on ield $\square \mathrm{a} \square$ ing. At least one urther $\square$ iln and ad acent $\square$ ine sha $t$ occur ust to the south o $\square$ the area $\square \mathrm{a} \square$ ed here. $\square$. South Craigend gradio $\square$ eter survey o $\square$ Grou $\square$ s 2 and 3 ilns (ollowing nu $\square$ Cering in A at le t) $) \square$ the $\square$ lan $\square$ area $\sqsubset$ etween Grou $\square 2$ ¿iln 4 and Grou $\square 3$ ¿iln 1 corres $\square$ onds to a tree where it was not $\square$ ossi $\square$ le to survey. $\square$ ote the $\square$ ossi $\square$ le su $\square$ sur ace structures ( $\square$ lu $\square$ ing $\square$ ) in the Ioor o $\square$ iln 3 in Grou $\square 2$ (centre o $\square$ igure) and $\square$ ossi $\square$ le connection $\square$ etween that $\sqsubset$ iln and the ad acent $\sqsubset$ iln 2.

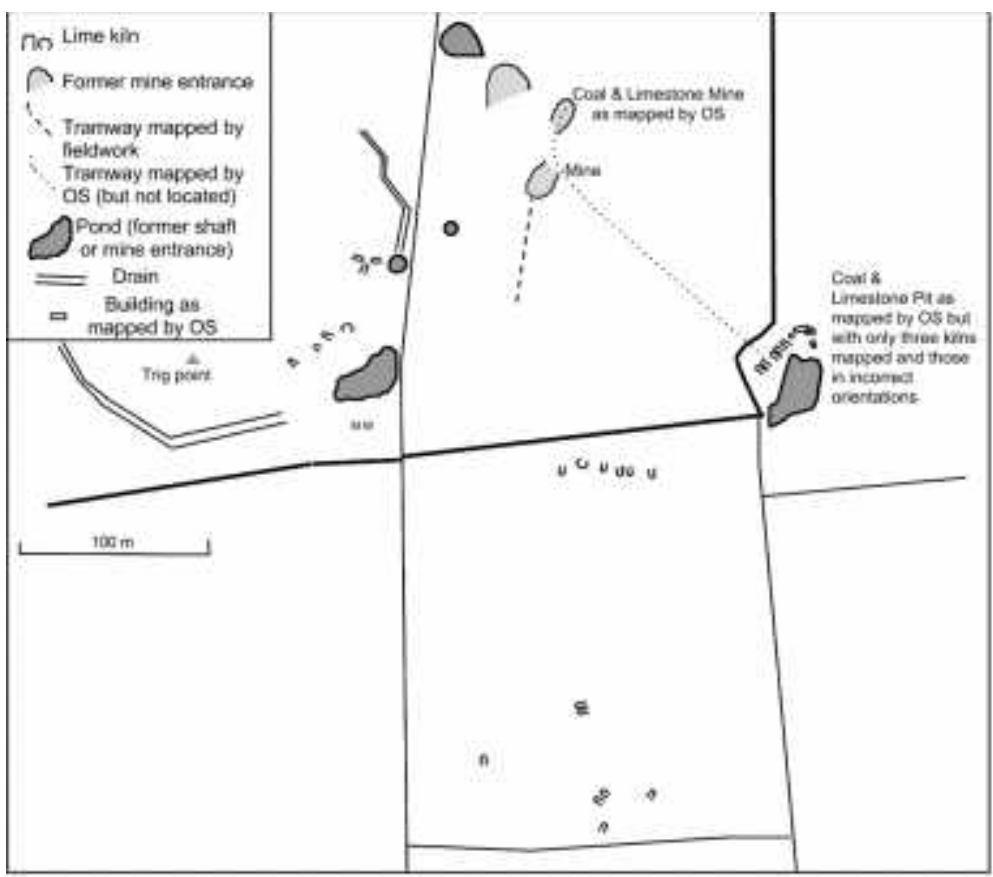

Figure 6. The area o $\square \square$ lairs $\square$ aith Trig station showing $\square$ ilns and $\square$ ines. OS $\square$ a $\square$ ing shows only the three ilns at centre right and no $\square$ ine entrances or drains.

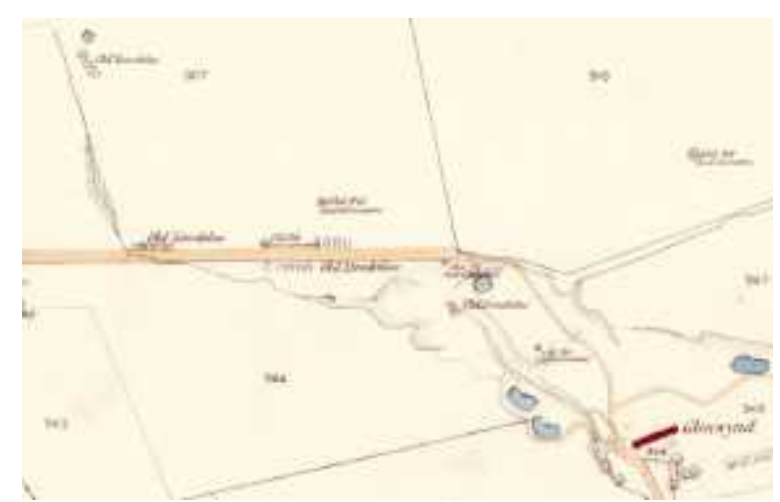

Figure 7. OS 1st edition $2 \square$ inch $\square \mathrm{a} \square \square$ ing o $\square 24 \mathrm{cla} \square \square$ iilns near Glenwynd (Stirling Sheet 27.16 (Ca $\square \square$ sie $\square$ arish) $\square$ surveyed $1860 \square$ u lished 186 $\square$ ). Ground survey con ir $\square$ s this $\square$ a $\square$ ing as 
accurate and as co $\square$ lete as it is $\square$ ossi $\square$ le to assess $\square$ given the considera $\square$ le distur $\square$ ance $\square$ y current orestry activities o $\square$ the northern hal $\square$ o $\square$ the area in this igure. (Re $\square$ roduced $\square$ y $\square$ er $\square$ ission o $\square$ the $\square$ ational Li $\square$ rary o $\square$ Scotland)

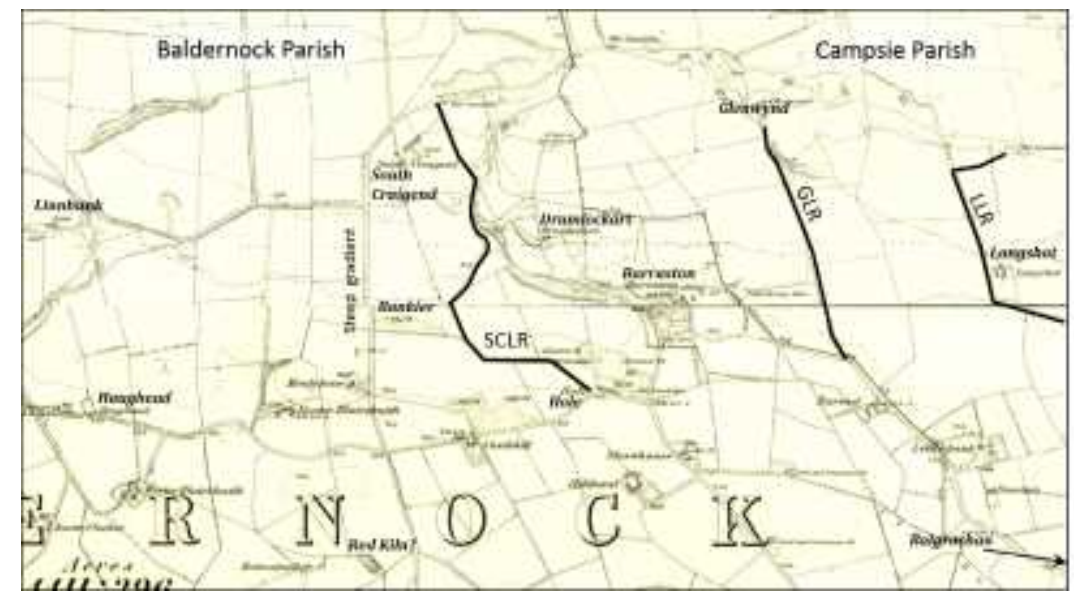

Figure 8. Li $\square$ e roads in $\square$ aldernoc $\square$ na $\square$ ing various localities $\square$ entioned in the te $\square \square$ ase $\square \mathbf{a} \square$ is the $\square$ id 19 th century OS 1st edition $6 \square \square \mathrm{a} \square$ (u $\square$ er $\square$ ortion: Stirlingshire sheet $27 \square$ surveyed $1860 \square$

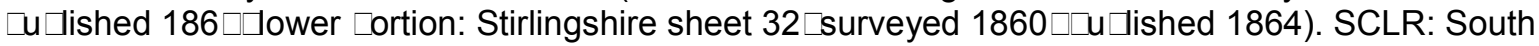
Craigend Li $\square$ e Road $\square$ GLR: Glenwynd Li $\square$ e Road LLR: Langshot Li $\square$ e Road. (Re $\square$ roduced $\square$ y $\square$ er $\square$ ission o $\square$ the $\square$ ational Li $\square$ rary o $\square$ Scotland)

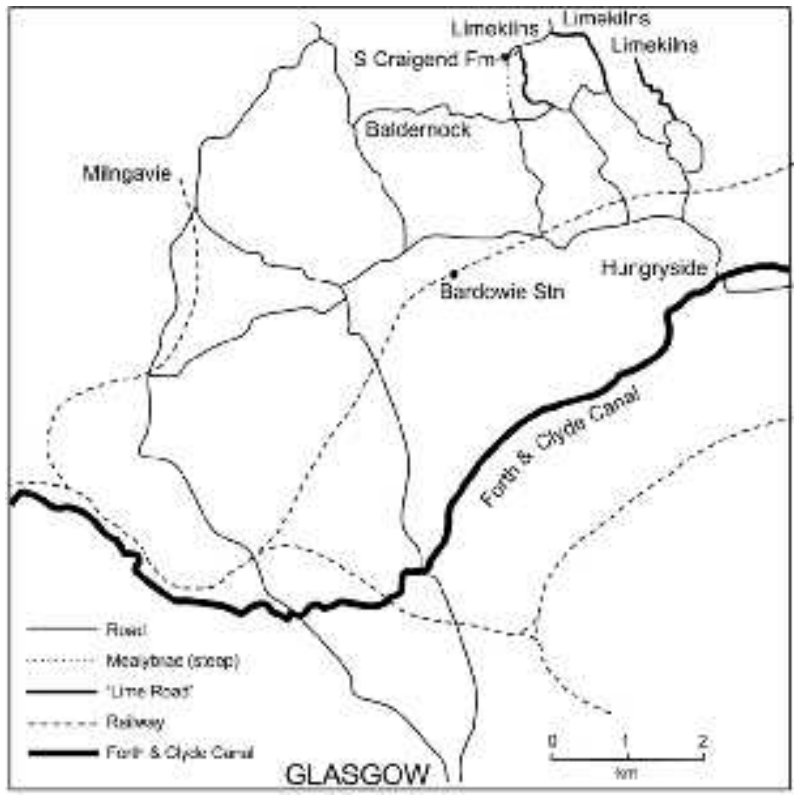

Figure 9. $\square$ aldernoc $\square \mathrm{Li} \square$ e Roads in relation to the whar $\square$ at Hungryside on the $\square$ orth and Clyde Canal (see $\square$ igure 9 or details and na $\square$ es o $\square \mathrm{Li} \square$ e Roads).

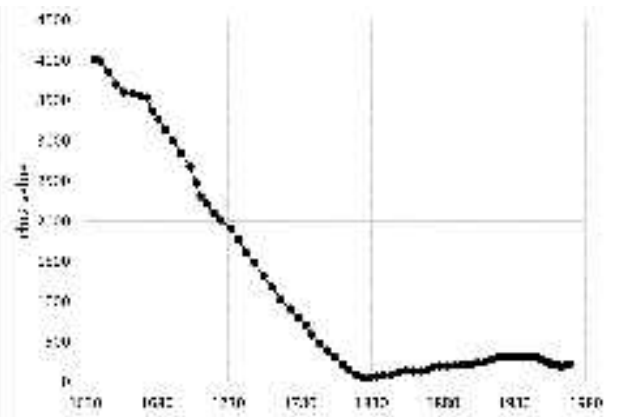

A.

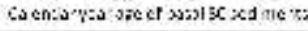

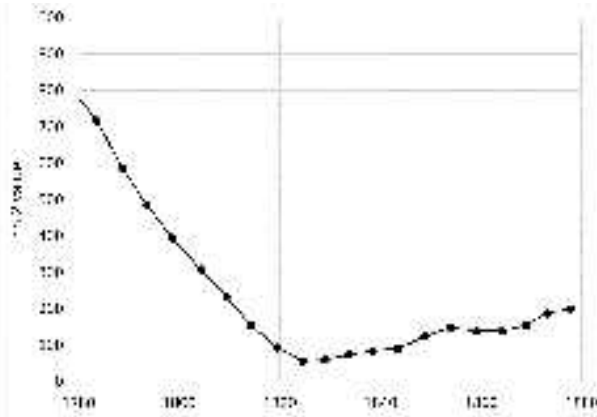

B. 
Figure 10. $\square$ lots $\circ \square \chi^{2}$ values or the lead $(\square \square)$ se $\square$ uences in the South Craigend water $\tan \square$ ( $\square$ igure $\square$ A) and the dated se $\square$ uence in Loch Lo $\square$ ond. (A) $\chi^{2}$ values or the goodness o $\square$ it $\sqsubset$ etween the $17 \square$ $\sqsubset$ oint South Craigend $\square$ ro ile and all $\square$ ossi $\square$ le $17 \square$ oint $\square$ roiles $\square$ oving $\square$ rogressively down through the dated Loch Lo $\square$ ond $\square \square$ se $\square$ uence $\square$ o $\square$ ed $\square$ art enlarged in ( $\square$ ). The $\square$ ini $\square$ u $\square \chi^{2}$ gives the $\square$ asal age $\square$ 1824. $\square$ say $182 \square \square$ or the onset o $\square$ sedi $\square$ entation in the South Craigend water tan $\square$ se $\square$ uence (and hence the assu $\square$ ed age o $\square$ the onset o $\square$ decline o the South Craigend li $\square$ e o $\square$ erations).

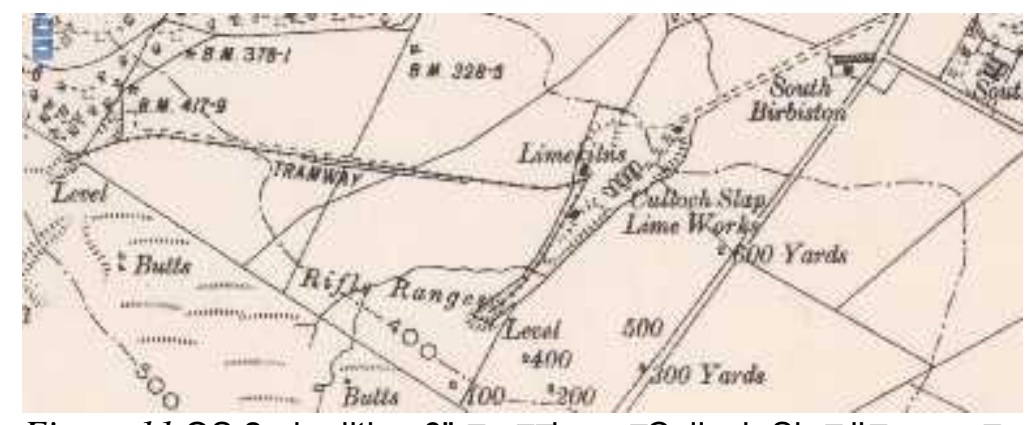

Figure 11.OS 2nd edition 6" $\square \mathrm{a} \square \square$ ing o $\square$ Culloch Sla $\square$ li $\square$ e wor $\square$ s showing re $\sqsubset$ uilt $\square$ ilns and new tra $\square$ way (Stirlingshire Sheet 27.S $\square$ revised 1896 $\square$ u $\square$ lished 1899). The elevated ridge that carried this second tra $\square$ way is still clear in the ield. (Re $\square$ roduced $\square$ y $\square$ er $\square$ ission o $\square$ the $\square$ ational Li $\square$ rary o $\square$ Scotland)

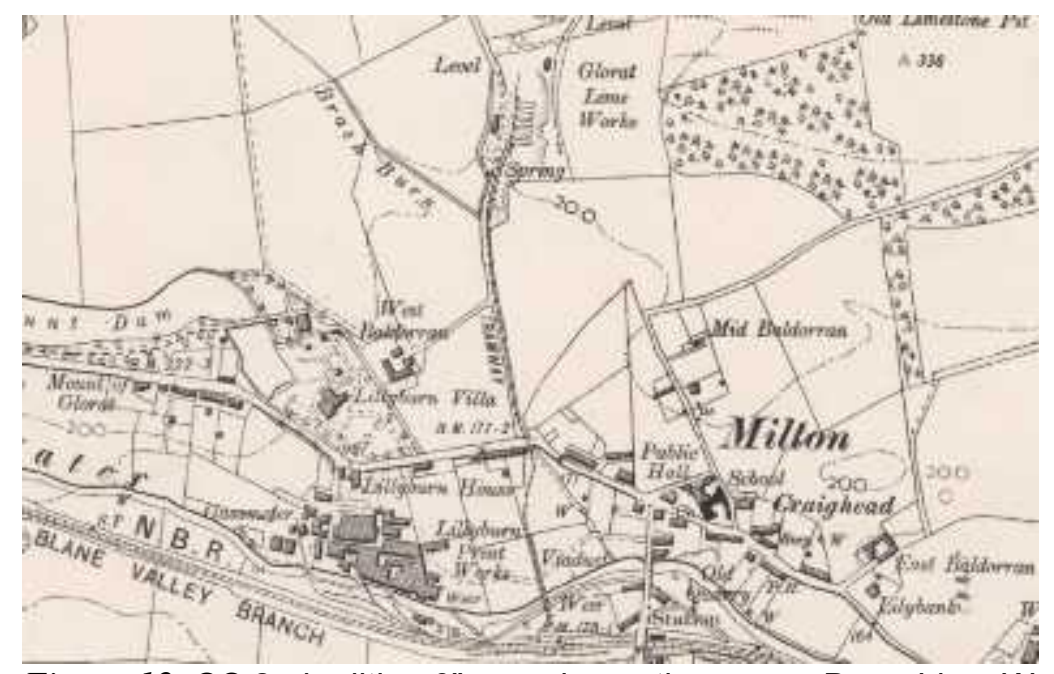

Figure 12. OS 2nd edition 6" $\square \mathrm{a} \square$ ing o $\square$ the or $\square$ er Derry Li $\square$ e Wor $\square$ s at $\square$ aldoran redevelo $\square$ ed in the secnd hal $\square$ o the $19^{\text {th }}$ century as the Glorat Li $\square$ ewor $\sqsubset$ s showing tra $\square$ ways connecting $\square$ ilns to the $\square$ ine north o the $\square$ ilns and to the $\square$ ainline railway to the south. (Re $\square$ roduced $\square$ y $\square \operatorname{er} \square$ ission o the $\square$ ational Li $\square$ rary o $\square$ Scotland).

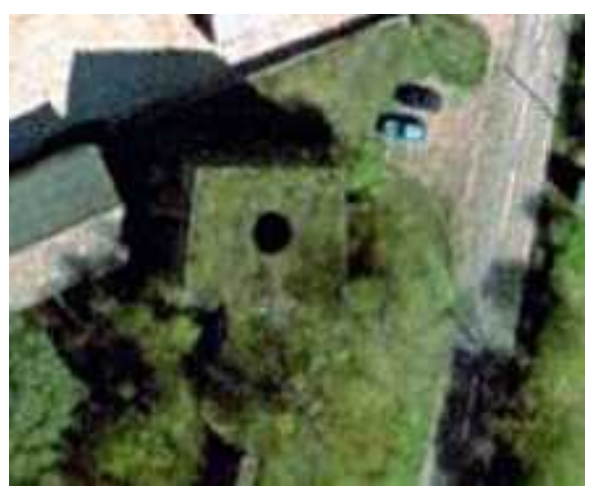

Figure 13. Google $\square$ arth i $\square$ age o $\square$ the draw $\square$ iln at the or $\square$ er Cults Li $\square$ ewor $\square \square \square$ itlessie $\square \square$ ie (eastern Scotland). $\square$ ote the $\square$ assive s $\square$ uare $\square$ asonry structure surrounding and su $\square$ orting the $\square$ iln $\square$ ot (the central circular eature). 